\title{
Results of the Tritium Survey of Fourmile Branch and its Seeplines in the F- and H-Areas of SRS: September 1996 and 1989-1996 Trending
}

by

J. W. Koch, II

Westinghouse Savannah River Company

Savannah River Site

Aiken, South Carolina 29808

K. L. Dixon

\section{MASTER $y^{4 !}$}

DATRIBUTHON OF THIS DOCUMEN I UNAMITED

\section{DOE Contract No. DE-AC09-89SR18035}

This paper was prepared in connection with work done under the above contract number with the U. S.

Department of Energy. By acceptance of this paper, the publisher and/or recipient acknowledges the U. S. Government's right to retain a nonexclusive, royalty-free license in and to any copyright covering this paper, along with the right to reproduce and to authorize others to reproduce all or part of the copyrighted paper. 


\section{Results of the Tritium Survey of Fourmile Branch and its Seeplines in the F-and H-Areas of SRS: September 1996 and 1989-1996 Trending (U)}

J. W. Koch II and K. L. Dixon, Environmental Analysis Section

PEREIVED

ANG 201998

OSTI

Approved by: Dobarne \&ledew

D.B. Moore-Shedrow, Manager

Environmental Sciences and Technology Department

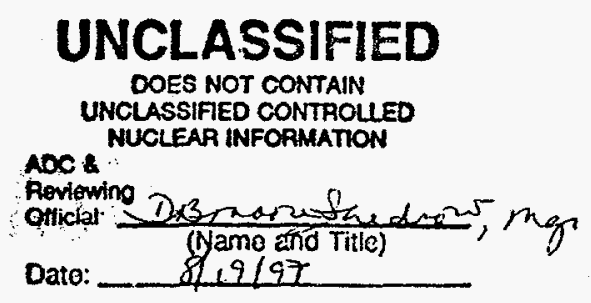

Westinghouse Savannah River Company

Savannah River Site

Aiken SC 29808

) Prepared for the U. S. Department of Energy under contract no. DE-AC09-89SR18035

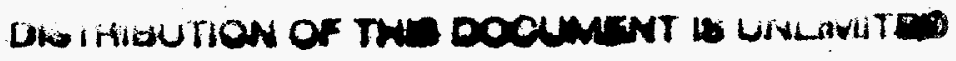




\section{DISCLAIMER}

This report was prepared as an account of work sponsored by an agency of the United States Government. Neither the United States Government nor any agency thereof, nor any of their employees, makes any warranty, express or implied, or assumes any legal liability or responsibility for the accuracy, completeness, or usefulness of any information, apparatus, product, or process disclosed, or represents that its use would not infringe privately owned rights. Reference herein to any specific commercial product, process, or service by trade name, trademark, manufacturer, or otherwise does not necessarily constitute or imply its endorsement, recommendation, or favoring by the United States Government or any agency thereof. The views and opinions of authors expressed herein do not necessarily state or reflect those of the United States Government or any agency thereof.

This report has been reproduced directly from the best available copy.

Available to DOE and DOE contractors from the Office of Scientific and Technical Information, P.O. Box 62, Oak Ridge, TN 37831; prices available from (615) 576-8401.

Available to the public from the National Technical Information Service, U.S. Department of Commerce, 5285 Port Royal Road, Springfield, VA 22161. 


\section{DISCLAIMER}

Portions of this document may be illegible in electronic image products. Images are produced from the best available original document. 
Results of the Tritium Survey of Fourmile Branch and its Seeplines in the F-and H-Areas of SRS: September 1996 and 1989-1996 Trending $(U)$

J. W. Koch II and K. L. Dixon

Prepared for the U. S. Department of Energy under contract no. DE-AC09-89SR18035 
)

\section{This page is intentionally blank}




\section{Table of Contents}

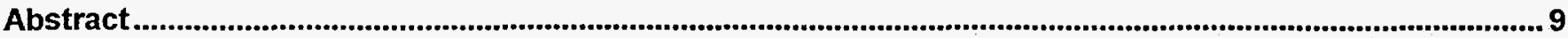

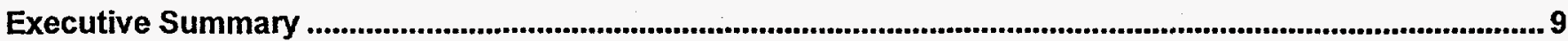

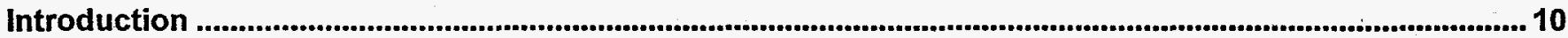

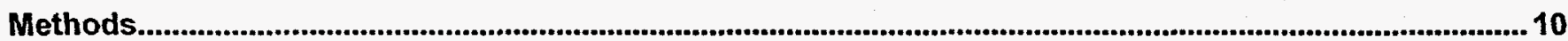

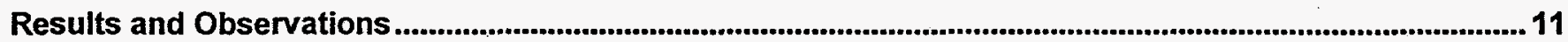

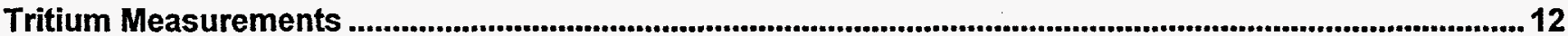

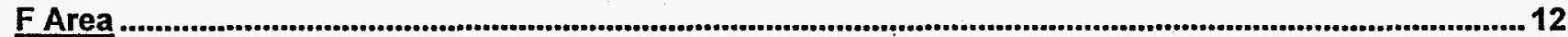

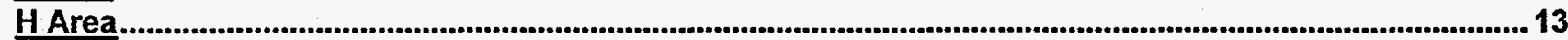

Conductivity Measurements.......................................................................................................................................... 13

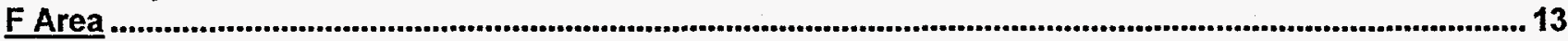

H Area

pH Measurements, F-and H-Area Seepline .............................................................................................. 13

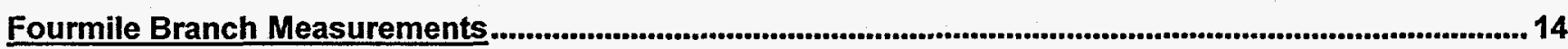

Solid Waste Disposal Facility (643-E) Seepline Measurements...................................................................... 14

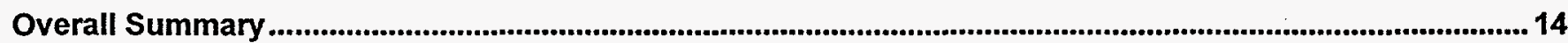

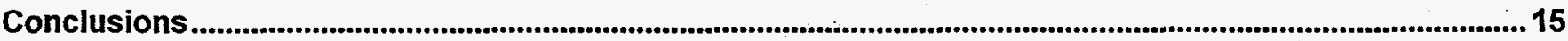

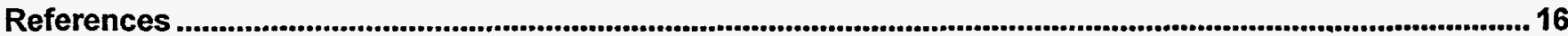




\section{List of Figures}

Page

Figure 1 Location of F-Area Seepage Basins and Seepline Sampling Points

Figure 2 Location of H-Area Seepage Basins, Seepline Sampling Points, and Sampling Points below 643-E

Figure 3

Flow Schematic with Capped Seepage Basins'

Figure 4

Flow Schematic during Seepage Basin Operation

Figure 5

Diagram of the Tritium Plumes Migrating from F- and H-Area Seepage Basins

Figure 6

Comparison of Monthly Rainfall to the Long Term Average (1961-1994)

Figure 7

Comparison of Tritium Concentrations for Selected F-Area Seepline Locations

Figure 8

Comparison of Tritium Measurements for Selected H-Area Seepline Locations

Figure 9

Comparison of Conductivity Measurements for Selected F-Area Seepline Locations

Figure 10

Figure 11

Comparison of Conductivity Measurements for Selected H-Area Seepline Locations

Figure 12

Comparison of pH Measurements for Selected F-Area Seepline Locations

Figure 13

Comparison of pH Measurements for Selected H-Area Seepline Locations

Figure 14

Comparison of Tritium Concentrations for Selected Fourmile Branch Locations

Figure 15 Comparison of Conductivity Measurements for Selected Fourmile Branch Locations 25

Figure 16 Comparison of pH Measurements for Selected Fourmile Branch Locations 26

Figure 17 Comparison of Tritium Concentrations for Selected Fourmile Branch Locations 26

Figure 18 Comparison of Conductivity Measurements Seepline below 643-E

Figure 19 Comparison of pH Measurements for Seepline below 643-E

Figure 20 Tritium and Conductivity Trends for F-Area Seepline

Figure 21 pH Trends for F-Area Seepline 28

Figure 22 Scatter Plot of Tritium Concentration for F-Area Seepline (1989-1996)

Figure 23 Tritium and Conductivity Trends for H-Area Seepline

Figure 24 pH Trends for H-Area Seepline

Figure 25

Scatter Plot of Tritium Concentration for H-Area Seepline (1989-1996

Comparison of Tritium concentrations for Seepline below 643-E

Figure 26

Comparison of Conductivity concentrations for Seepline below 643-E 32

Figure 27 Scatter Plot of Tritium Concentration for Seepline below 643-E (1992-1996) 33

Figure 28 Tritium, Conductivity, and pH for Sample Location FMC001F (Fourmile Branch)

Figure 29 Tritium, Conductivity, and pH for Sample Location FMC001H (Fourmile Branch) 35

Figure 30 Tritium, Conductivity, and pH for Sample Location FMC001H (Fourmile Branch) 35

Note: Figures 1 through 18 present September 1996 sampling event information Figures 19 through 30 present overall summary information (1989-1996) 


\section{List of Tables}

Page

Table 1 Comparison of Monthly Rainfall to the Long Term Average

36

Table 2 Comparison of F-Area Seepline Measurements for Tritium ,Conductivity ,and pH for March 1989, March 1996, and September 1996 Sampling Events

Table 3 Comparison of H-Area Seepline Measurements for Tritium, Conductivity, and pH for March 1989, March 1996, and September 1996 Sampling Events

Table 4 Comparison of Fourmile Branch Stream Measurements for Tritium, Conductivity and pH for March 1989, March 1996, and September 1996 Sampling Events

Table 5 Comparison of 643-E Seepline Measurements for Tritium ,Conductivity ,and pH for March 1989, March 1996, and September 1996 Sampling Events

Table 6 Average Tritium, Conductivity, and pH Values for F-And H-Area Seeplines (1989-1996)

Table 7

Average Tritium and Conductivity, Values for Seepline Below 643-E (1992-1996)

Table 8

Tritium Concentrations for Fourmile Branch (1992-1996) 
)

This page is intentionally blank 


\title{
Results of the Tritium Survey of Fourmile Branch and its Seeplines in the F and H Areas of SRS: September 1996 and 1989-1996 Trends
}

\author{
J.W. Koch II and K.L. Dixon
}

\section{Abstract}

The Environmental Sciences Section (ESS), now known as the Environmental Sciences and Technology Department (ES\&TD) of the Savannah River Technology Center (SRTC) conducted a quarterly monitoring program of the Fourmile Branch (FMB) stream and its associated seepline located down gradient from the F- and H-Area Seepage Basins beginning May 1992 and ending in May 1995. The quarterly tritium survey was changed to a semi-annual schedule in 1996. This report details the results of the second semi-annual event in 1996 and summarizes the tritium data beginning with the baseline 1989 and 1992 sampling events. The primary focus of this program is to measure and track changes in tritium levels. Specific conductivity and $\mathrm{pH}$ were also measured and tracked. The measurements from this survey (September 1996) exhibited similar tritium levels, conductivity measurements, and $\mathrm{pH}$ values to data from the previous tritium surveys. The results of this tritium survey and stream monitoring data (Looney et al., 1993) indicate that the tritium plume resulting from the past operation of the seepage basins continues to flush from the seeplines and wetlands to Fourmile Branch. The overall summary results indicate that the tritium plumes are surfacing in somewhat localized areas along the F-Area and 643-E seeplines.

\section{Executive Summary}

In September 1996 the Environmental Sciences Section (ESS) surveyed the Fourmile Branch seepline down gradient from the F- and H-Area Seepage Basins for tritium, specific conductivity, and $\mathrm{pH}$. This survey was the second of two surveys scheduled during FY96 to monitor the movement of contaminants from the basins since closure in 1990 . Surface-water samples were collected from 60 locations along the seepline and from three stream locations along Fourmile Branch. The seepline locations included 22 from F Area, 22 from $H$ Area, and 16 from the seepline south of 643-E, which is a decommissioned area in the Solid Waste Disposal Facility. Forty-four of the locations were sampled in 1989 by the Savannah River Technology Center as part of an extensive characterization study (Haselow et al. 1990). Tritium activities in both F- and H-Area seeplines in September 1996 were significantly lower than the activities measured by Haselow et al. (1990). However, there were four locations from the
September 1996 survey that showed a increase in . tritium activity over $10 \%$ above the March 1989 results. September 1996 conductivity measurements exhibited the same trends as tritium activities. This was true in both $\mathrm{F}$ and $\mathrm{H}$ Areas.

The average seepline $\mathrm{pH}$ was approximately the same as the last survey which was conducted in March 1996. The results continue to indicate that conditions have somewhat stabilized from extremely acid ( $\mathrm{pH}<4.5$ ) to slightly acid (combined average $\mathrm{pH}$ of 5.4) which is closer to normal for this type of wetland. The seepline south of $643-\mathrm{E}$, along a tributary of Fourmile Branch, is influenced by tritium migrating from the Burial Ground Complex. The tributary. (old F-Area effluent ditch) is a natural drainage that received effluent discharge from $F$ Area Separations prior to the construction of the engineered effluent canal. The September 1996 tritium activities on the east side of the natural 
drainage ranged from 16 to $496 \mathrm{pCi} / \mathrm{ml}$ and on the west side from 209 to $19,100 \mathrm{pCi} / \mathrm{ml}$. The tritium activity measured in the stream of the natural drainage was $18,500 \mathrm{pCi} / \mathrm{ml}$. These results continue to suggest that the tritium outcrop area has been delineated by the sampling locations established on the west side of the drainage channel. Conductivity and $\mathrm{pH}$ measurements taken on both sides of the drainage were similar to those recorded in March 1996 , and were within the range of normal values for this wetland. The maximum tritium levels have declined from $59,400 \mathrm{pCi} / \mathrm{ml}$ at sample location FHB018 to a maximum of $19,100 \mathrm{pCi} / \mathrm{ml}$ at this same sample location. Similar decreases have been seen at the other west side sample locations.

\section{Introduction}

Seepage basins in the $F$ and $H$ Areas of SRS received low-level radioactive waste effluent from the chemical separation processes in the General Separation Area, (GSA). The basins retained the effluent and allowed it to be slowly released into the soil. The waste effluent consisted principally of sodium hydroxide, nitric acid, low levels of various radionuclides, and some metals (Killian et al., 1985a and 1985b). Discharges of tritiated water to the seepage basins accounted for a majority of the radioactivity (Fenimore and Horton, 1972).

The Savannah River Technology Center conducted an extensive study designed to characterize the shallow groundwater outcropping into Fourmile Branch (FMB) and its associated seepline in 1988 and 1989 (Haselow et al., 1990). As a part of this study, Haselow et al. (1990) surveyed for tritium, $\mathrm{pH}$, and conductivity. Researchers found low $\mathrm{pH}$ and elevated conductivity and tritium values along the seeplines and concluded that contaminants leaching from the $\mathrm{F}$ - and $\mathrm{H}$-Area Seepage Basins were impacting the wetlands below the basins. SRS stopped discharges to the seepage basins in 1988 and capped and sealed the basins in 1990 to isolate the contaminants from direct rainfall. Scientists hypothesized that after the elimination of the contaminant source, natural groundwater flow from annual rainfall would flush the remaining contaminant plume out of the shallow groundwater over time. After the contaminant plume in the shallow groundwater is flushed out, the impacted wetland systems immediately down gradient from the basins should recover.

To investigate this hypothesis, a quarterly sampling program was established in May 1992 and concluded in May 1995. ESS sampled 44 of the seepline locations sampled by Haselow et al. (1990) for tritium, $\mathrm{pH}$, and specific conductivity. The 1996 sampling program is intended to complement semiannual sampling of the seepline for selected Appendix IX constituents, which began in July 1992 and in 1996, was conducted annually. A report summarizing results from the semi-annual sampling program has been completed (Dixon and Rogers, 1993e, Dixon, Koch, and Rogers, 1995). The Haselow et al. (1990) results established the baseline to which the results from the quarterly tritium sampling program are compared. These collection points were chosen as the baseline because they are the only data available that were collected before the basin discharges were discontinued. The Haselow et al. (1990) data should be representative of conditions immediately prior to closing the basins.

There was expressed concern about the source of tritium and other contaminants that possibly emanate from an area in the southwest corner of 643-E rather than from the closed basins. To investigate this possibility, numerous sampling locations on the H-Area seepline south of 643-E were established and were incorporated into the quarterly sampling plans beginning in March 1993 and continuing in FY96.

\section{Methods}

ESS conducted the second in a series of two FY96 sampling events for tritium in September 1996. Sampling locations were the same as those selected in the quarterly tritium surveys. These locations, according to 1989 data, exhibited high and low values for the three variables of concern. Attempts were made to establish an even ground coverage along both seeplines. ESS collected 56 samples from the seeplines in F and H Area: 22 from the F-Area seepline, 18 from the $\mathrm{H}$-Area seepline, and 14 from the FHB seepline south of 643-E Area. Four of the seepline locations were dry. One sample was taken from the old effluent stream. ESS also collected 
three stream samples from locations on Fourmile Branch. Figures 1 and 2 approximate these sampling locations.

Prior to sampling for the first quarterly survey in May 1992, the Health Protection Department (HPD) collected soil samples from several locations along both seeplines and monitored them for gamma radioactivity. HPD did not detect gamma radiation above levels of concern; therefore, ESS selected rubber boots and disposable rubber gloves as protective clothing to prevent skin contact with seepline water during sampling operations.

Seepline sampling locations had been previously marked and labeled with PVC stakes. Samples were collected within a three foot radius of the PVC stake by boring a hole into the soil with a small soil auger, generally six inches and not more than eighteen inches deep to obtain a sample. To collect water for

$\therefore$ tritium analysis, polyethylene sample containers (25 $\mathrm{ml}$ ) were dipped into the water until full and then capped. The outside of each container was then rinsed with deionized water and sealed in a small polyethylene bag to minimize the possibility of cross contamination. The small bags were then sealed in a large polyethylene bag. General Engineering Laboratories (GEL) performed the tritium analysis for the standard and duplicate samples and the Environmental Monitoring Section (EMS) performed the analysis on split samples and the samples with activity levels that exceeded 2000 $\mathrm{pCi} / \mathrm{ml}$ total activity counts.

ESS measured specific conductivity and $\mathrm{pH}$ in situ with conductivity and $\mathrm{pH}$ electrodes (WSRC Procedure Manual L14.1, 1992a and 1992b). The electrodes were rinsed with deionized water after each sampling. All sampling equipment was thoroughly rinsed with deionized water at the end of each day.

\section{Results and Observations}

Parameters measured at seepline sampling locations fluctuate throughout the year. Seepline measurements are made on water collected from fixed locations at the initial point of outcropping, or toe, of the contaminant plume in the streamside wetland. Because the plume is dynamic (i.e., influenced by weather and other activities in the area) seepline monitoring is sensitive to both long term changes and seasonal/transient influences. Climatic and seasonal conditions, especially rainfall amounts influence measured concentrations Groundwater flow paths in $F$ and $H$ Area are complex, as illustrated in Figures 3 and 4. Recharge to the groundwater is primarily due to infiltration of rainwater (rainfall minus runoff and evapotranspiration). Groundwater then moves laterally, down and to Fourmile Branch and its tributaries.

As the water travels toward the stream, additional infiltration forces up-gradient water deeper. Near the stream, the flow lines rise to the surface, emerging between the seepline and the stream (which acts as the groundwater "drain"). This typical vertical trajectory, a path curving downward near the groundwater divide and then upward into draining surface water, is shown as flow lines on Figures 3 and 4.

Figure 3 shows the flow lines without contaminated water from the seepage basins and Figure 4 shows the addition of contaminated flow lines resulting from $\mathrm{F}$ and $\mathrm{H}$ Area operation of the basins. The theoretical plume geometry is clearly confirmed by the real vertical profile of the F-Area Seepage Basin plume based on the detailed grid wells available in the 1970s (Looney et al., 1993). Changes in the water balance in the area influence the flow velocity and tend to move the plume either deeper or shallower and cause the location of the contaminated water to move. This is especially important to data interpretation if the "toe" of the plume is shifting relative to the fixed sample locations. Figure 5 summarizes the projected changes in the plume based on a range of transient activities. Increased rainfall (or other activities that increase infiltration such as harvesting trees) result in increased plume velocity and movement downward and away from the seepline. This decreases contaminant concentrations at the seepline sampling locations. Less infiltration decreases plume velocity and causes the plume to move upward and outcrop closer to the basins. This results in increased contaminant concentrations as measured at the seepline sampling locations. 
Low rainfall for a few month's prior to sampling is expected to increase constituent concentrations, and high rainfall decreases constituent concentrations in the shallow groundwater at the seepline intercept. Rainfall measured at SRS at the weather station in F Area from June 1996 through September 1996 was $60.7 \mathrm{~cm}$. From 1961 to 1994 , the average rainfall measured for this same period was $49.1 \mathrm{~cm}$. This indicates that rainfall amounts in the sampling area were well above average for the few months prior to this sample period. Figure 6 shows a comparison of October 1995-September 1996 rainfall to the long term average (1961-1994). It is hypothesized that above average rainfall observed in the area for this period would cause contaminant concentrations to decrease at sample locations closer to the basins and to increase at the more distant locations. This increase in infiltration causes the toe of the plume to migrate downward through the soil profile and the arrival point of the toe to move towards FMB and $\because$ away from the basins. Note that the direction of the plume flow always remains the same, only the plume velocity and outcrop location changes relative to the changes in infiltration.

Tritium concentrations at four sample locations were above the March 1989 readings, with these sample locations showing an average tritium activity increase of $785 \mathrm{pCi} / \mathrm{ml}$. Generally; these are the most distant sample location points from the closed basins along Fourmile Branch. Figures 7 through 12 show comparisons of March 1989 with May 1995 and September 1996 tritium, conductivity, and $\mathrm{pH}$ measurements for locations on the F- and H-Area seepline. Data for the first thirteen surveys can be found in Dixon, Rogers, and Looney (1992, 1993a; 1993b, 1993c, 1993d and 1993e and 1994), Rogers et al. (1994a, 1994b, and 1994c) and Koch and Dixon (1994 1995, and 1996). Figures 13 through 15 show the data for the Fourmile Branch stream . locations. Figures 1,6 through 18 show the data for the sampling locations along the old effluent seepline and include one stream sample from the branch channel south of 643-E. These sampling locations were identified with the prefix FHB.

\section{F-and H-Area Seepline \\ Tritium Measurements}

Figures 7 and 8 show tritium activity at $F$ and $H$ Area for the September 1996 sampling event. Tritium concentrations increased at 9 - sample locations, while 29 locations either decreased or were relatively unchanged compared to the March 1996 sampling event. There were four dry sites. Overall, sampling has shown a declining trend in tritium concentrations at the F-and $\mathrm{H}$-Area seeplines (Figures 19 and 20).

It is important to note that total tritium fluxes to the wetlands and FMB have steadily declined since basin closure (Looney et al., 1993) and that overall results of the tritium survey support this finding. Differences in tritium concentrations measured at seepline sampling locations from one sampling event to the next represent seasonal variability and variable rainfall as well as changes due to the flushing of the plume from the wetland system. Variability may also result from reduction in plume size along margins.

\section{$\underline{\text { F Area }}$}

September 1996 tritium values in the F-Area seepline ranged from 7-7150 pCi/ml (Figure 6 and Table 2). One of the 22 sampling locations was dry, and one sampling location had a tritium activity that exceeded the 1989 measurements by more than ten percent. No sample exceeded the maximum value of $14,000 \mathrm{pCi} / \mathrm{ml}$ measured in March 1989 at this seepline.

As with data from previous sampling èvents, a Wilcoxon signed-rank test was conducted to compare September 1996 tritium activities to March 1989 activities. The Wilcoxon signed-rank test uses the sign and the magnitude of the rank of the differences between pairs of measurements to compare nonparametric data (Daniel, 1978). This test was chosen because it allows comparisons of paired data without assumptions of normality. If the $P$ value is less than or equal to 0.05 , then the September 1996 tritium levels are significantly less , than the March 1.989 tritium levels. The results from this test gave a P value $<0.002$. This test shows that the September 1996 concentrations were significantly lower than the 1989 concentrations for this seepline. 
Results of the Tritium Survey of Fourmile Branch and

its Seeplines in the F and H Areas of SRS: September 1996

\section{$\underline{\text { HArea }}$}

Tritium values in the H-Area seepline ranged from 20-1980 pCi/ml (Figure 8 and Table 3 ). Three of the 22 sampling locations were dry, and three sampling locations had tritium activities that exceeded the 1989 measurements by more than ten percent. These locations, HSP071, HSP097, and HSP103 are among the furthest locations from the closed basins. No sample exceeded the maximum value of 24,000 $\mathrm{pCi} / \mathrm{ml}$ measured in March 1989 at this seepline.

Figure 22 shows the downward trend of tritium concentrations and the conductivity trends in this area. It presents the mean of the tritium concentrations from each sampling event beginning with the March 1989 event (Table 6). Figure 23 shows the $\mathrm{pH}$ trends using the mean $\mathrm{pH}$ of each sampling event.

As with data from $\mathrm{F}$ Area, a Wilcoxon signed-rank test was conducted to compare September 1996 tritium activities to March 1989 activities. The results showed that the September 1996 concentrations were significantly less $(\mathrm{P}<0.005)$ than the 1989 concentrations for $\mathrm{H}$ Area.

\section{$F$ - and H-Area Seepline Conductivity Measurements}

\section{$\underline{\text { FArea }}$}

Conductivity measurements in the F-Area seepline ranged from $28-1210 \mu \mathrm{S} / \mathrm{cm}$ (Figure 9 and Table 2). Due to the variability of conductivity measurements, only differences of $100 \mu \mathrm{S} / \mathrm{cm}$ or more are considered significant. Of the 22 locations sampled at the F-Area seepline, two of the locations measured more than $100 \mu \mathrm{S} / \mathrm{cm}$ above the 1989 measurements. A comparison of the results in Figures 7 and 9 suggests that conductivity follows the same general trends as the tritium activities. Using a Spearman rank correlation test for nonparametric data, it was found that the probability that tritium and conductivity exhibited independent trends was $\mathrm{P}<0.001$. The Spearman rank correlation coefficient was found to be $r_{s}=0.92$, suggesting that the two parameters are exhibiting dependent trends. This similarity is consistent with past results.
(Haselow et al., 1990). A rank correlation coefficient of 1.0 is a perfect correlation between variables.

\section{$\underline{\text { HArea }}$}

Conductivity measurements in the H-Area seepline ranged from 22-375 $\mu \mathrm{S} / \mathrm{cm}$ (Figure 10 and Table 3). None of the sampling locations, had a measurement of more than $100 \mu \mathrm{S} / \mathrm{cm}$ above the 1989 measurements. The Spearman rank correlation test for nonparametric data was used to investigate the correlation of $\mathrm{H}$ Area tritium activities and conductivity values. The probability that the two parameters exhibited independent trends was $\mathrm{P}<0.10$ The rank correlation coefficient $\left(r_{s}=0.35\right.$ ) for $H$ Area was less than that for $\mathrm{F}$ Area and suggests a much weaker correlation. In past tritium surveys, 1992 to March 1996, this correlation has been positive and significant.

\section{F-and $H$-Area Seepline pHMeasurements}

F-Area $\mathrm{pH}$ values ranged from 3.5 to 6.1 with an average value of 4.8 (Figure 11 and Table 2). $\mathrm{H}$ Area $\mathrm{pH}$ values ranged from 5.6 to 6.8 with an average of 6.1 (Figure 12 and Table 3). The $\mathrm{pH}$ for the entire seepline ( $\mathrm{F}$ and $\mathrm{H}$ Areas combined) averaged 5.4. This represents an increase of 0.5 units over the 4.9 average in 1989 and is slightly higher than the overall average for the May 1995 and March 1996 sampling events. An increase in $\mathrm{pH}$ will affect the solubility of metals in the soil which should improve the soil water chemistry and enhance the recovery of wetland vegetation stressed indirectly by low $\mathrm{pH}$.

Aluminum concentrations measured along the seepline in 1989 were high enough to be toxic to plants(Haselow et al., 1990). Increases in pH from an average of 4.9 in 1989 have likely reduced the amount of aluminum in solution and thereby reduced it as a possible source of plant toxicity. Concentrations of aluminum and other metals measured along the seepline in July 1992 were substantially lower than 1989 concentrations, consistent with the observed $\mathrm{pH}$.(Dixon and Rogers, 1993e), (Chappell et al, 1995). Field observations 
have revealed that vegetation in most of the stressed areas is making noticeable recovery (Nelson and Irwin, 1994; Nelson and Rogers, 1995). Studies have also shown that the toxicity of these areas is decreasing, (Nelson and Westbury, 1994; Westbury and Nelson, 1994).

\section{Fourmile Branch Measurements}

Figures 13 through 15 show the tritium, conductivity, and $\mathrm{pH}$ values for the Fourmile Branch stream sampling locations. Table 4 provides the data used in the figures. Tritium activities at these locations ranged $35-520 \mathrm{pCi} / \mathrm{ml}$. These values were consistent with previous data and show increases in tritium downstream as the seepline water enters the channel of Fourmile Branch. Conductivity measurements ranged from $49-62 \mu \mathrm{S} / \mathrm{cm}$ and $\mathrm{pH}$ ranged from 5.4 to 6.1 . Both conductivity and $\mathrm{pH}$ values were at near normal levels.

\section{Solid Waste Disposal Facility (643-E) Seepline Measurements}

The graphs in Figures 16 through 18 show tritium, conductivity, and $\mathrm{pH}$ values for the seepline and stream sampling locations south of 643-E, which is part of the Solid Waste Disposal Facility. Table 5 provides the data used in the figures. This seepline is along the natural drainage (old F-Area effluent ditch) that was used to discharge effluent from FArea separations prior to the construction of the engineered effluent canal.

Tritium activities for the locations on the east side of the drainage ranged from 16 to $496 \mathrm{pCi} / \mathrm{ml}$. Activities on the west side of the drainage ranged from 209 to $19,100 \mathrm{pCi} / \mathrm{ml}$. The tritium activity at the stream location in the drainage (FHB012) was $18,500 \mathrm{pCi} / \mathrm{ml}$.

The $\mathrm{pH}$ values ranged from 5.1 to 6.1 with an average of 5.5. Conductivity measurements on both sides of the drainage were near background at most locations and ranged from 18 to $80 \mu \mathrm{S} / \mathrm{cm}$. Conductivity values are typical of the conductivity values being reported in the water table wells in the vicinity of the old F-Area effluent ditch (EMS,
1993). Using the Spearman rank correlation test a significant correlation was found between conductivity and tritium for these locations $\left(r_{s}=\right.$ $0.69)$. This indicates that these two variables behave dependently. In the past this correlation was very weak.

These results are consistent with the Haselow et al. (1990) results for the west side sample locations of the 643-E seepline, particularly near location HSP103. Haselow et al. (1990) found that down gradient from 643-E, conductivity values were near background while tritium concentrations were elevated.

This was attributed to tritiated wastes deposited in 643-E. Tritium activities measured along the seepline down gradient of 643-E (particularly sample points on the west side of the drainage) suggest that tritium migrating from 643-E and outcropping in this area is substantial. The appearance of tritium on the west side as opposed to the east side of the drainage suggests that soil material placed in the northern reaches of the natural drainage forced the tritium plume to outcrop down gradient. It appears that the groundwater containing tritium is moving below the fill material and outcropping on the west side of the drainage channel. The results suggest that the sampling locations on the west side of the drainage have delineated the tritium plume with the center located at or near FHB018.

Figure 30 was developed to show the tritium data from all the sampling events for this seepline area beginning with the 1992 sampling event. A majority of the tritium measured can be accounted for at four locations all on the west side of the drainage. These location are FHB013, 017, 018, and 019.

\section{Overall Summary}

\section{F- and H-Area Seeplines, 643-E and Fourmile Branch}

Figure 19 shows the downward trend of tritium concentrations for the F-Area seepline and the conductivity trends. This figure depicts the mean tritium and conductivity concentration from each sampling event beginning with the March 1989 
baseline event through the September 1996 sampling event (Table 6). Figure 20 shows the $\mathrm{pH}$ trends using the mean $\mathrm{pH}$ of each sampling event. Each sampling event since 1989 has shown a statistically significant decrease in tritium concentrations when compared to the 1989 baseline event.

Figure 21 shows the tritium data from all the sampling events for the F-Area seepline. It shows that a majority of the tritium measured can be accounted for at eight of the 22 sample locations. These locations, are FSP019, 026, 032, 034, 035, 040,204 , and 213 . Very little of the tritium plume has been detected east of sample location FSP040 or south and west of sample location FSP0213. It further appears that there are two distinct groupings of sample locations which delineate the bulk of the tritium plume from the seepage basins. These two groupings appear to be separated by Road C-4.

Figure 22 shows the downward trend of tritium concentrations for the H-Area seepline and the conductivity trends. This figure depicts the mean tritium and conductivity concentration from each sampling event beginning with the March 1989 baseline event through the September 1996 sampling event (Table 6). Figure 23 shows the $\mathrm{pH}$ trends using the mean $\mathrm{pH}$ of each sampling event. Each sampling event since 1989 has shown a statistically significant decrease in tritium concentrations when compared to the 1989 baseline event.

Figure 24 shows all the tritium data from all the sampling events conducted for the H-Area seepline. The sampling locations that have had the highest and lowest tritium values over the sampling interval, 1989-1996, can be seen in this figure.

Figures 25-27 summarize the tritium concentrations, conductivity, and $\mathrm{pH}$ measurements of each sampling event. The delineation of the contamination is apparent in Figure 25. Figure 27 shows that a majority of the contaminant plume appears at four sample locations. These locations are on the west side of the drainage and are identified as FHB013, 017, 018, and FHB019.
Figures 28-30 show the tritium concentrations, conductivity, and $\mathrm{pH}$ measurements for the Fourmile Branch sample locations from 1992-1996. Each point on these figures represents the actual concentrations or readings and are not averages.

\section{Conclusions}

F- and H-Area Seeplines, Seepline Below 643-E and Fourmile Branch

- Tritium concentrations measured at most locations during September 1996 remained relatively unchanged compared to the previous sampling event yet are significantly lower than the 1989 baseline tritium levels.

- Total tritium fluxes to the wetlands and FMB have steadily declined since basin closure (Looney et al., 1993) and overall results from the tritium survey support this finding. These findings support the hypothesis that the tritium plume in $\mathrm{F}$ and $\mathrm{H}$ Area is being flushed from the shallow groundwater.

- A majority of the tritium detected along the FArea seepline is at two localized areas which can be identified by eight of the 22 sample locations. These eight sample locations are FSP019, 026, 032, 034, 035, 040, 204, and 213.

- The tritium concentrations have steadily decreased at the west side sample locations along the seepline below 643-E since August 1993.

- A major portion of the tritium detected along the seepline below 643-E is on the west side of the drainage at four sample locations. These four sample locations are FHB013, 017, 018, and 019.

- Differences in tritium concentrations measured at seepline sampling locations from one sampling event to the next represent seasonal and rainfall variability as well as changes due to flushing of the contaminant plume from the wetland system. No correction has been made for tritium decay because of the short time 
groundwater system and should be based on long-term surface water, seepline, and groundwater monitoring data and not on quarterly changes in concentrations at seepline monitoring locations.

\section{Solid Waste Disposal Facility (643-E) Seepline}

Evaluation of data from 16 seepline locations south of the 643-E Area indicates that tritium migrating from 643-E is outcropping at the F- Area effluent ditch, particularly on the west side of the stream channel. It appears that sampling locations on the west side of the ditch have delineated the tritium outcrop area with the present climatic and hydrologic conditions. Data indicates that the tritium has decreased over the past eight sampling events.

\section{References}

Daniel, W.W. 1978. Applied Nonparametric Statistics. Houghton Mifflin Company, Boston, MA.

Dixon, K.L. and V.A. Rogers. 1992. Results of the First Quarter Tritium Survey of the F- and HArea Seeplines: May 1992. WSRC-TR-92-304, Westinghouse Savannah River Company, Savannah River Technology Center, Aiken, SC

Dixon, K.L. and V.A. Rogers. 1993a. Results of the Second Quarter Tritium Survey of the F- and HArea Seeplines: September 1992. WSRC-TR-93129, Westinghouse Savannah River Company, Savannah River Technology Center, Aiken, SC.

Dixon, K.L. and V.A. Rogers. 1993b. Results of the Third Quarter Tritium Survey of the F- and HArea Seeplines: December 1992. WSRC-TR-93284, Westinghouse Savannah River Company, Savannah River Technology Center, Aiken, SC.

Dixon, K.L. and V.A. Rogers. 1993c. Results of the Fourth Quarter Tritium Survey of the F- and HArea Seeplines: March/April 1993. WSRC-TR93-526, Westinghouse Savannah River
Company, Savannah River Technology Center, Aiken, SC.

Dixon, K.L. and V.A. Rogers. 1993d. Results of the Quarterly Tritium Survey of Fourmile Branch and its Seeplines in the F- and H-Areas of SRS: June 1993. WSRC-TR-93-656, Westinghouse Savannah River Company,. Savannah River Technology Center, Aiken, SC.

Dixon, K.L. and V.A. Rogers. 1993e. Semi-Annual Sampling of Fourmile Branch and Its Seeplines in the F and H Areas of SRS: July 1992. WSRCTR-93-289, Westinghouse Savannah River Company, Savannah River Technology Center, Aiken, SC.

Dixon, K.L., and V.A. Rogers, and B.B. Looney. 1994. Results of the Quarterly Tritium Survey of Fourmile Branch and its Seeplines in the F and H Areas of SRS: September 1993 (U) WSRC-TR-94-0286-ESS, Westinghouse Savannah River Company, Savannah River Technology Center, Aiken, SC.

Dixon, K.L., J.W. Koch, and V.A. Rogers. 1995. Semi-Annual Sampling of Fourmile Branch and Its Seeplines in the $F$ and $H$ Areas of SRS: February 1993, July 1993, April 1994. (U) WSRC-TR-94-0454, Rev. 1, Westinghouse Savannah River Company, Savannah River Technology Center, Aiken, SC. 
Environmental Monitoring Section. 1993. The Savannah River Site's Ground Water Monitoring Program, Second Quarter Report. ESH-EMS930097, Westinghouse Savannah River Company, Aiken SC.

Fenimore, J.W. and J.H. Horton. 1972. Rating History and Environmental Effects of Seepage Basins in Chemical Separations Areas of the Savannah River Plant. DPST-72-548, E.I. du Pont de Nemours and Company, Savannah River Laboratory, Aiken, SC.

Haselow, J.S., M. Harris, B.B. Looney, N.V. Halverson, and J.B. Gladden. 1990. Analysis of Soil and Water at the Fourmile Branch Seepline Near the F and $H$ Area of SRS (U). WSRC-RP90-0591, WSRC-TR-92-304, Westinghouse Savannah River Company, Savannah River Technology Center, Aiken, SC. Savannah River Laboratory, Aiken, SC.

Killian, T.H., N.L. Kolb, P. Corbo, and I.W. Marine. 1985a. F-Area Seepage Basins. DPST-85-704, E.I. du Pont de Nemours and Company, Savannah River Laboratory, Aiken, SC.

Killian, T.H., N.L. Kolb, P. Corbo, and I.W. Marine. 1985b. H-Area Seepage Basins. DPST-85-706, E.I. du Pont de Nemours and Company, Savannah River Laboratory, Aiken, SC.

Koch, J.W. and K.L. Dixon. 1994. Results of the Quarterly Tritium Survey of Fourmile Branch and its Seeplines in the F and $H$ Areas of SRS: December 1994. (U) WSRC-TR-95-0300, Westinghouse Savannah River Company, Savannah River Technology Center, Aiken, SC.

Koch, J.W. and K.L. Dixon. 1995. Results of the Quarterly Tritium Survey of Fourmile Branch and its Seeplines in the F and H Areas of SRS: May 1995. (U) WSRC-TR-95-0369, Westinghouse Savannah River Company, Savannah River Technology Center, Aiken, SC.
Koch, J.W. and K.L. Dixon. 1996. Results of the Quarterly Tritium Survey of Fourmile Branch and its Seeplines in the F and H Areas of SRS: March 1996. (U) WSRC-TR-96-0215, Westinghouse Savannah River Company, Savannah River Technology Center, Aiken, SC.

Looney, B.B., J.S. Haselow, C.M. Lewis, M.K. Harris, D.E. Wyatt, C.S. Hetrick. 1993. Projected Tritium Releases from F \& H Area Seepage Basins and the Solid Waste Disposal Facilities to Fourmile Branch (U). WSRC-RP93-459, Westinghouse Savannah River Company, Savannah River Technology Center, Aiken, SC. Savannah River Laboratory, Aiken, SC.

Nelson, E.A. and Irwin, J.E. - 1994. Current Vegetation Characteristics within Tree-Kill Zones of $F$ and $H$ Areas (U) WSRC-TR-94-0233 Westinghouse Savannah River Company, Savannah River Technology Center, Aiken, SC.

Nelson, E. A. and Westbury, H.M. Jr. 1994 Letuce Seed Germination and Root Elongation Toxicity Evaluation of the F-Area Seepline Soils (U) WSRC-TR-94-0510 Westinghouse Savannah River Company, Savannah River Technology Center, Aiken, SC.

Nelson, E.A. and Rogers, V.A. 1995. Survival of Planted Tupelo Seedlings in F- and H-Area TreeKill Zones (U) WSRC-TR-95-0025 Westinghouse Savannah River Company, Savannah River Technology Center, Aiken, SC.

Rogers, V.A., K.L. Dixon, and B.B. Looney. 1994a. Results of the Quarterly Tritium Survey of Fourmile Branch and its Seeplines in the $F$ and $H$ Areas of SRS: December 1993. (U) WSRC-TR94-0342, Westinghouse Savannah River Company, Savannah River Technology Center, Aiken, SC. 
Rogers, V.A., KL. Dixon, and B.B. Looney. 1994 b. Results of the Quarterly Tritium Survey of Fourmile Branch and its Seeplines in the F and $H$ Areas of SRS: March 1994. (U) WSRC-TR-940408, Westinghouse Savannah River Company, Savannah River Technology Center, Aiken, SC.

Rogers, V.A., K.L. Dixon, and B.B. Looney. 1994c. Results of the Quarterly Tritium Survey of Fourmile Branch and its Seeplines in the F and $H$ Areas of SRS: June 1994. (U) WSRC-TR-940441, Westinghouse Savannah River Company, Savannah River Technology Center, Aiken, SC.

Westbury, H.M. Jr. and Nelson, F.A. 1994. Plant Community Development Within the F- and $\mathrm{H}$ Area Tree-Kill Zones (U) WSRC-TR-94-0544 Westinghouse Savannah River Company, Savannah River Technology Center, Aiken, SC. 


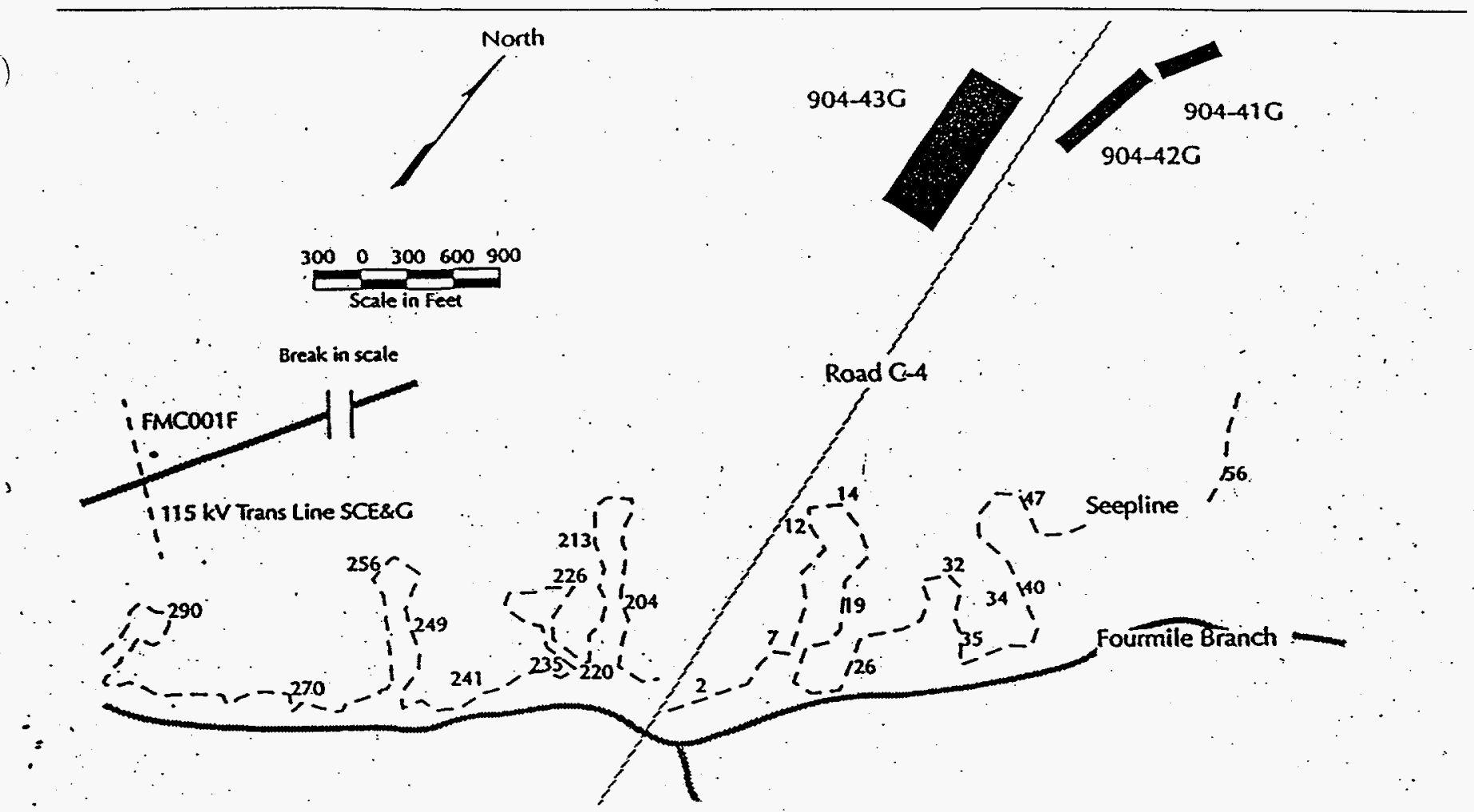

Figure 1. Location of F-Area Seepage Basins and Seepline Sampling Points.

).

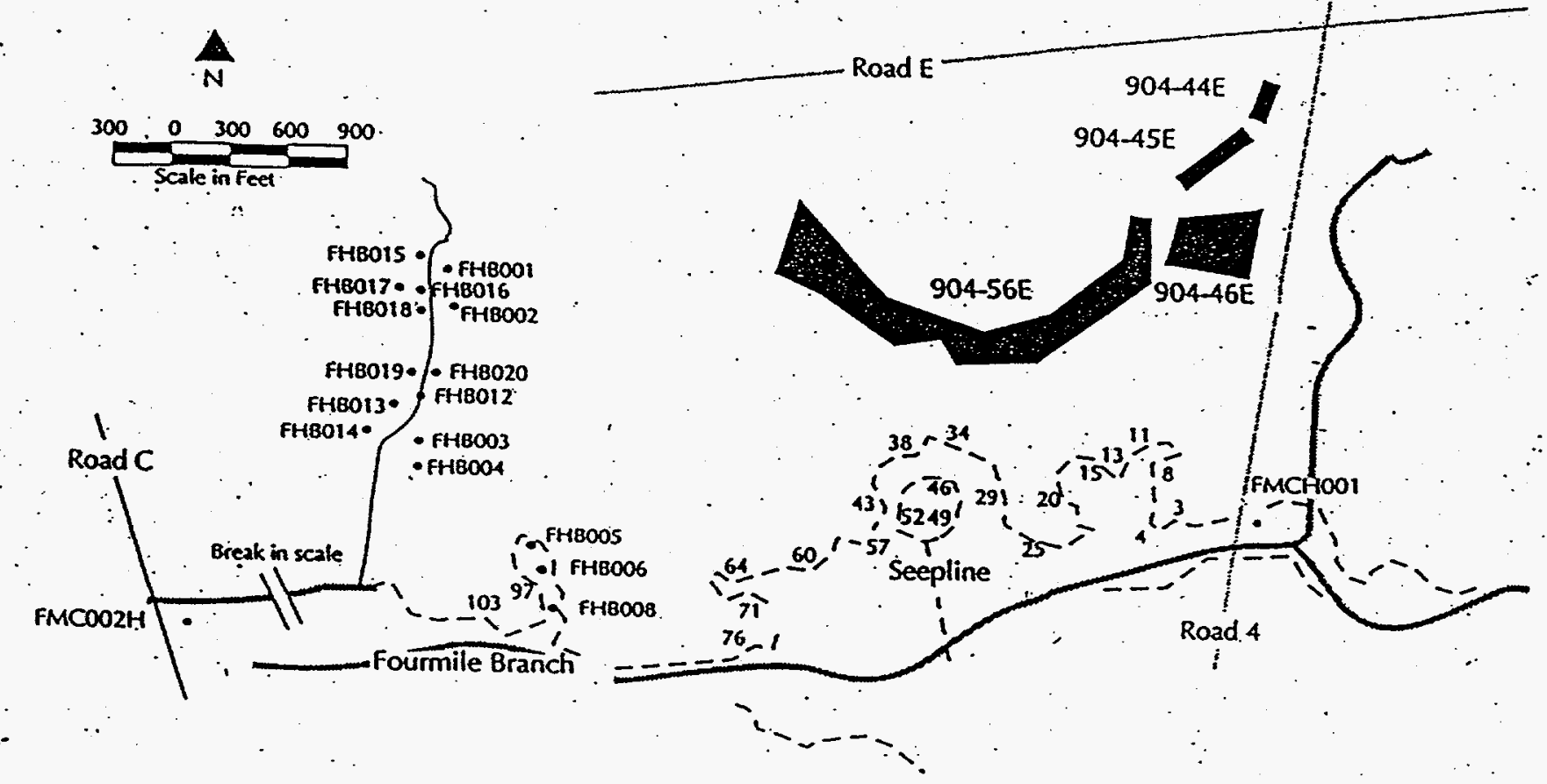

Figures 2. Location of H-Area Seepage Basins and Seepline Sampling Points and FHB Sampling Points. 


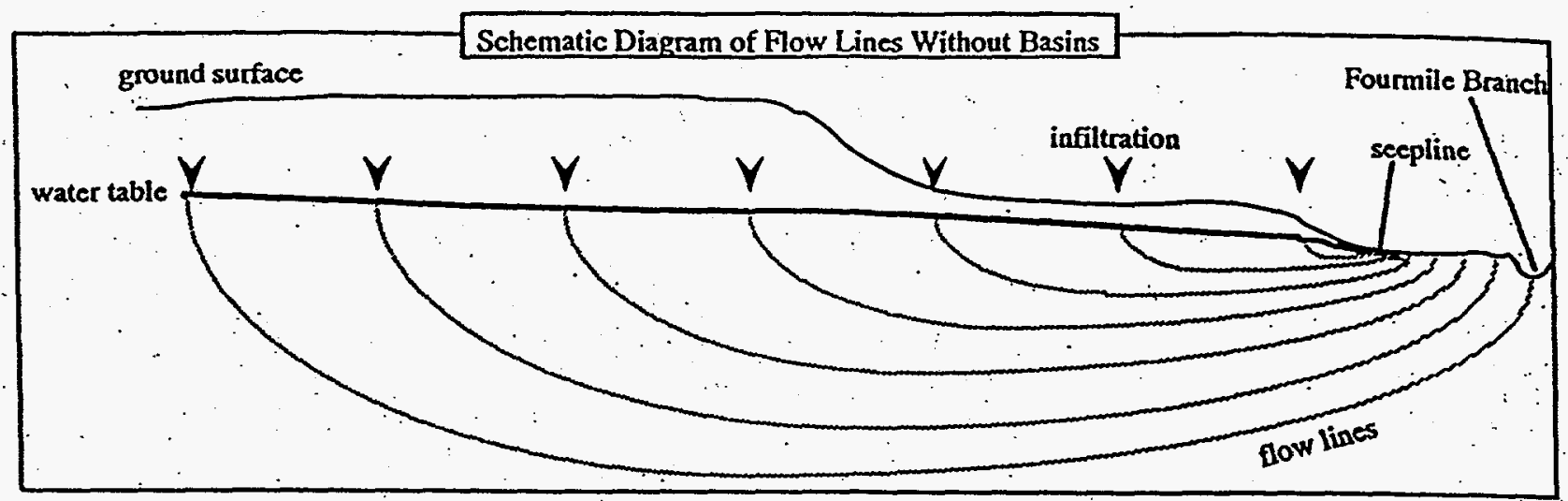

Figures 3. Schematic Diagram of Flow Lines in the Shallow Groundwater at the F- and H-Area without Seepage Basins.

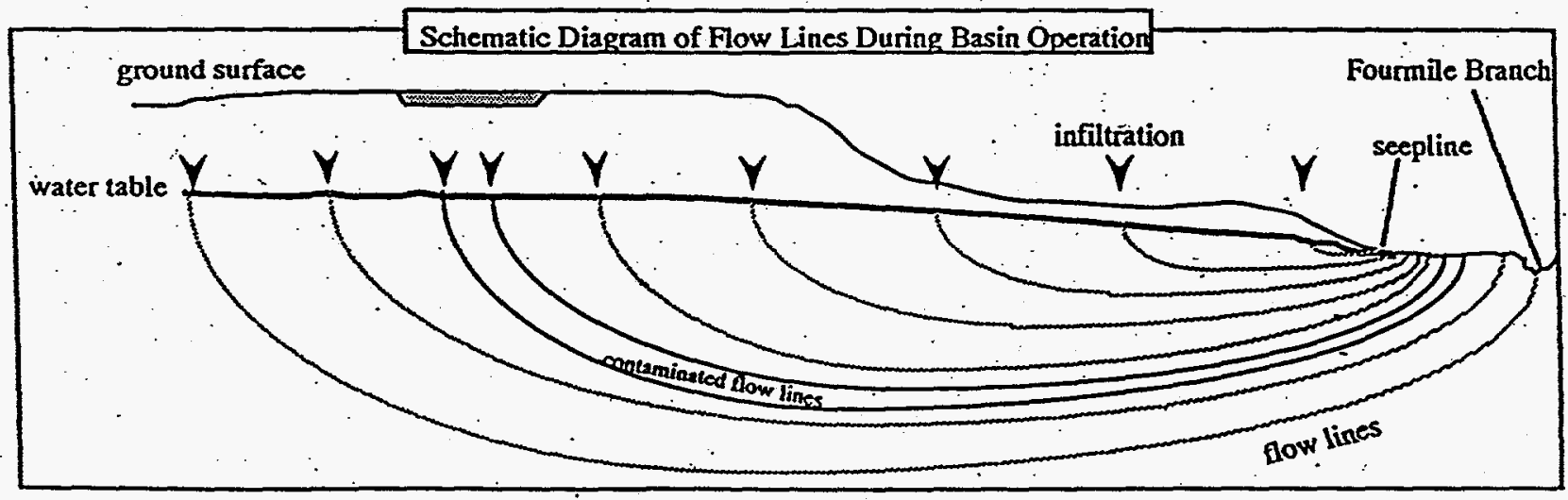

Figures 4. Schematic Diagram of Flow Lines in the Shallow Groundwater at the F-and H-Area during Basin Operation. 


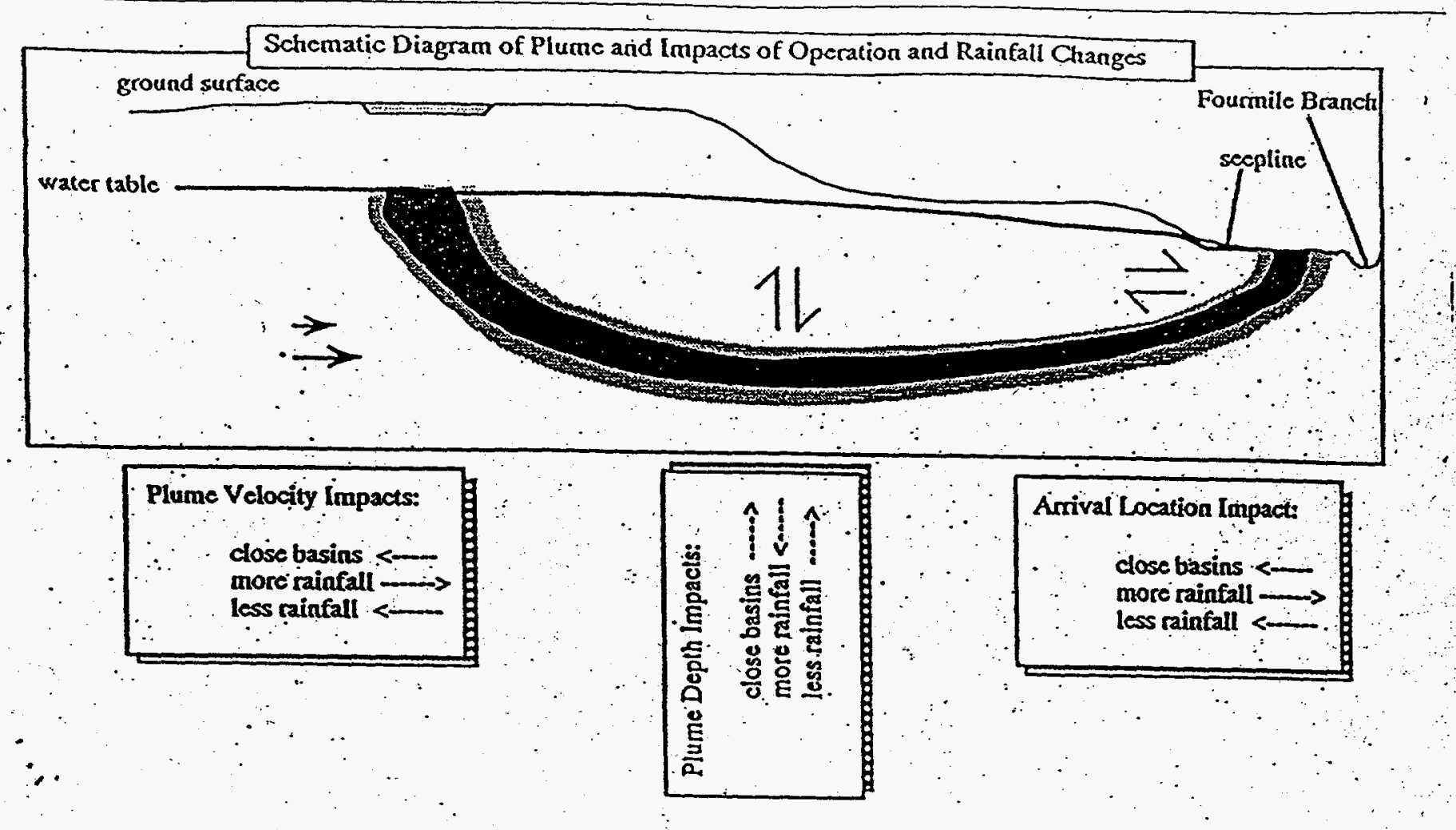

Figure 5. Schematic Diagram of the Tritium Plume Migrating from F- and H-Area Seepage Basins

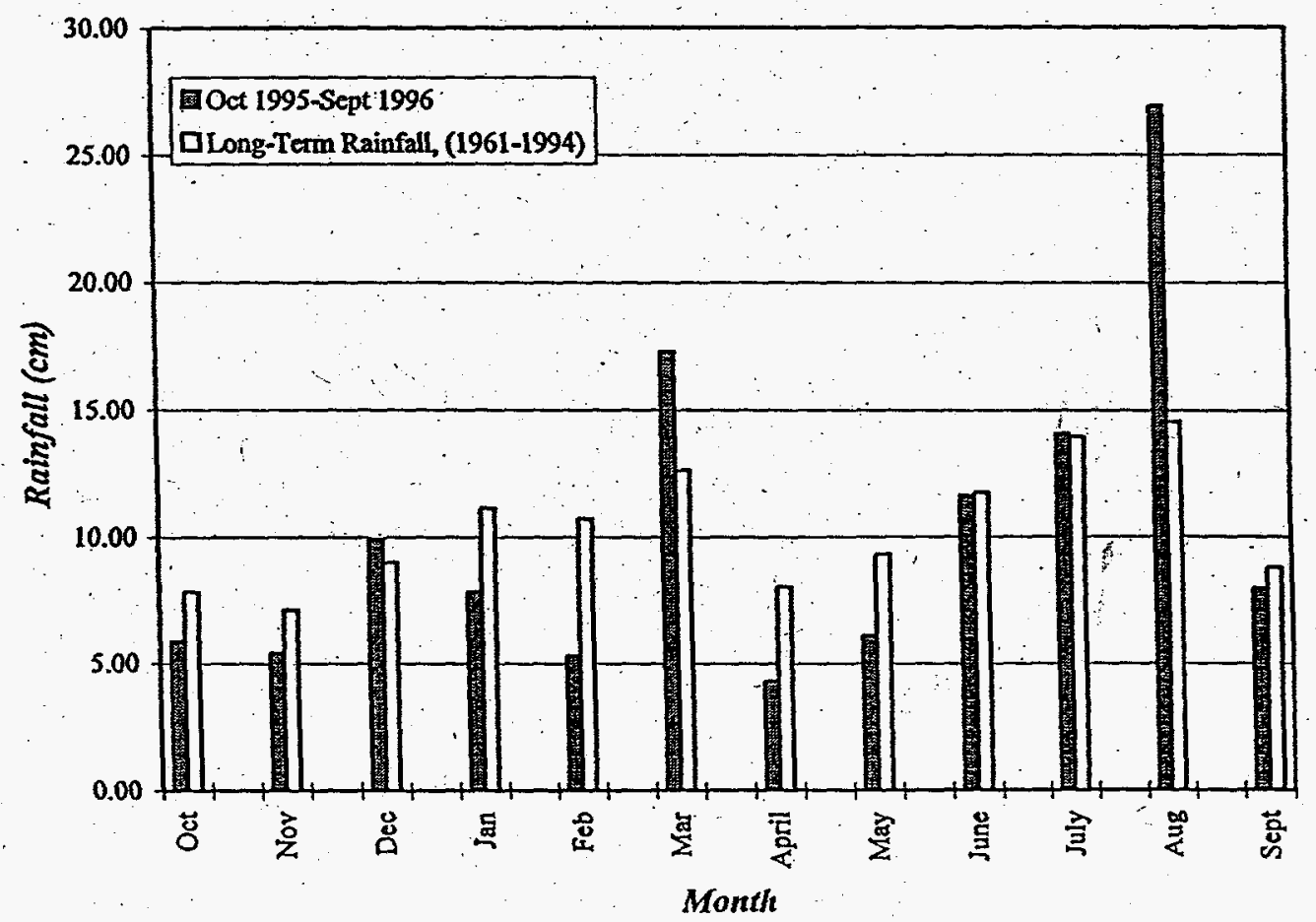

Figure 6. Comparison of October 1995-September 1996 Monthly Rainfall to the Long Term Average (1961-1994) for the F-Area Weather Station 


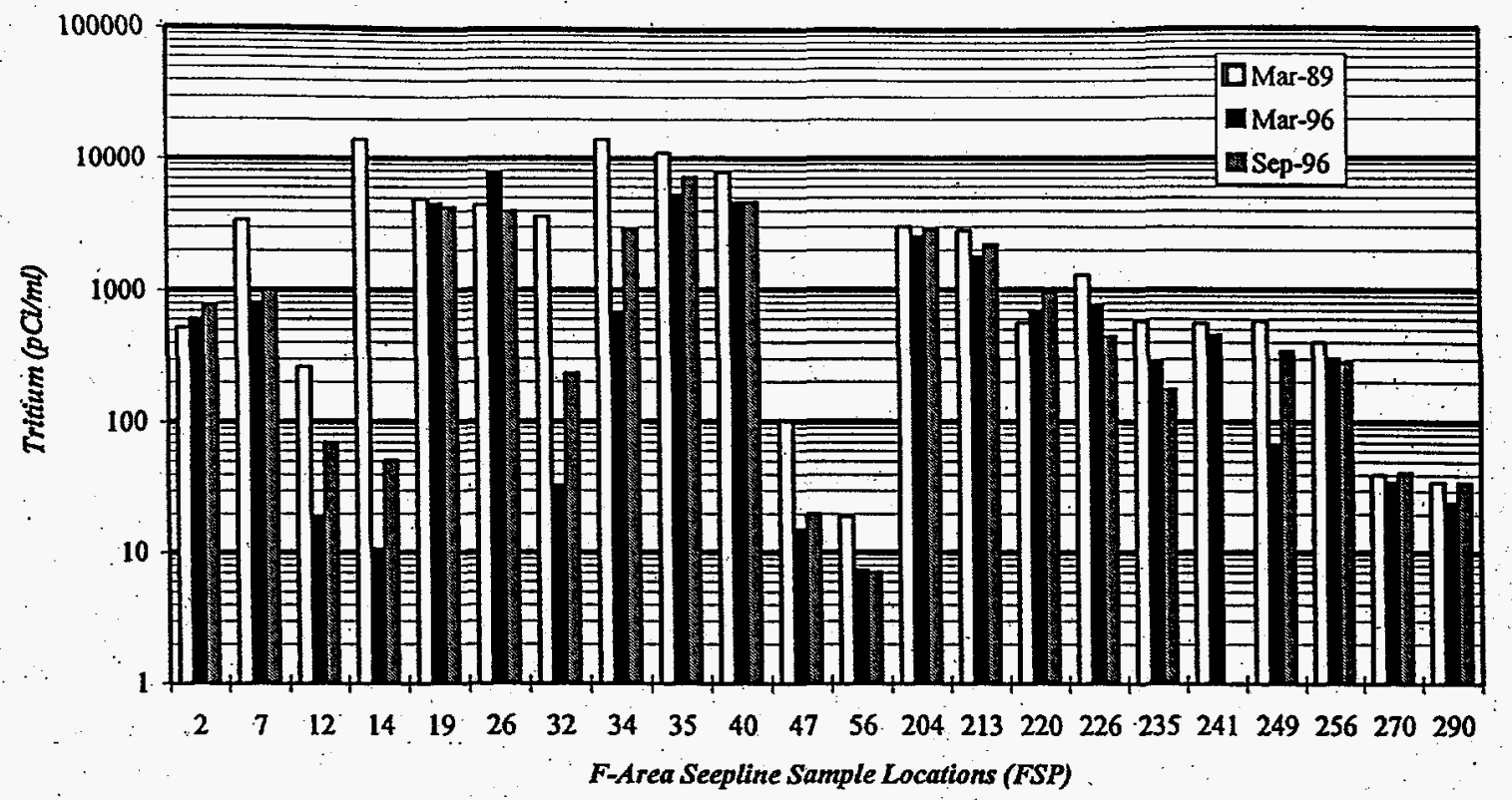

$\because$

Figure 7. Comparison of Tritium Concentrations for Selected F-Area Seepline Locations

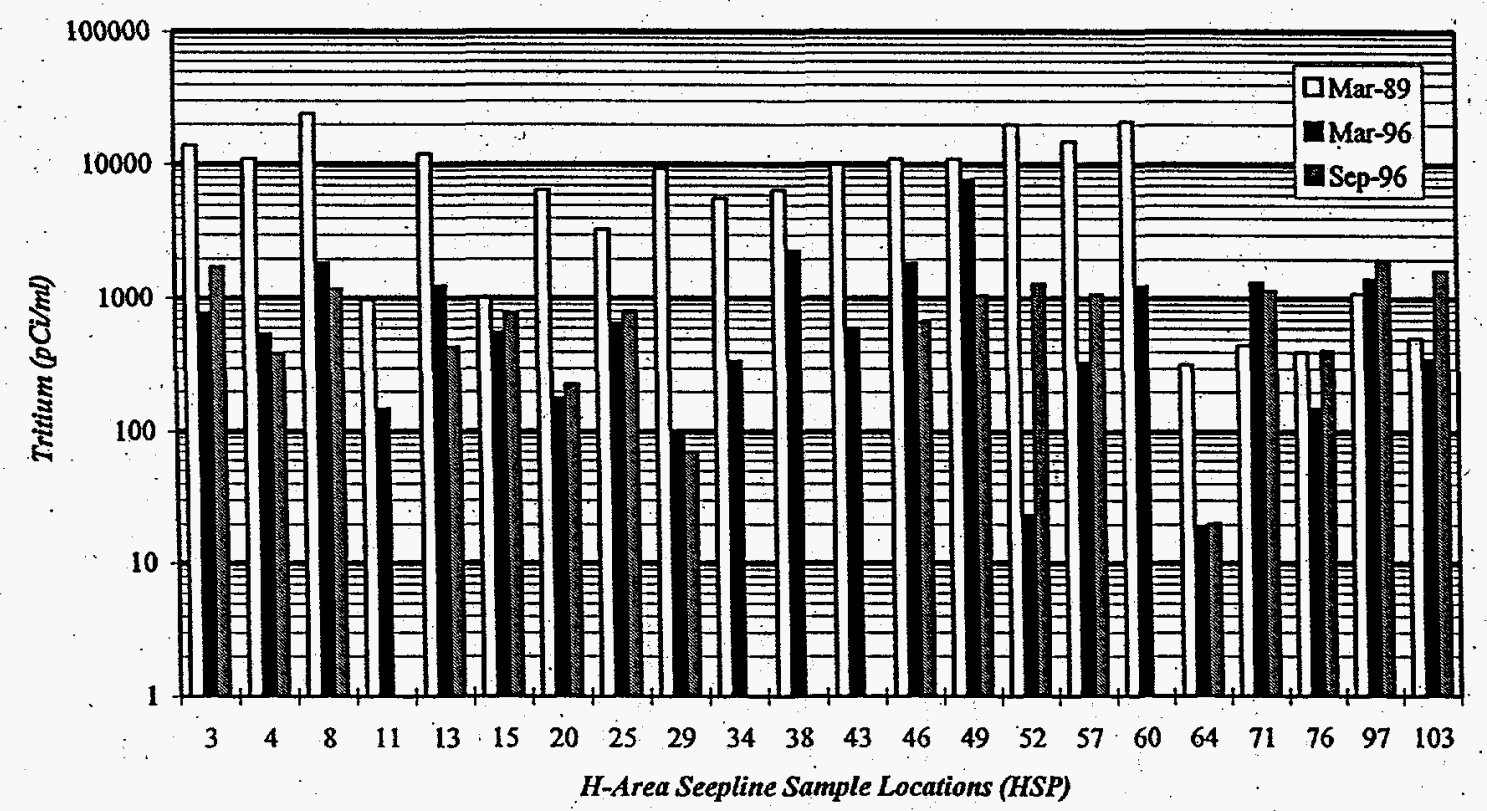

Figure 8. Comparison of Tritium Measurements for Selected H-Area Seepline Locations 
Results of the Tritium Survey of Fourmile Branch and

its Seeplines in the F and H Areas of SRS: September 1996

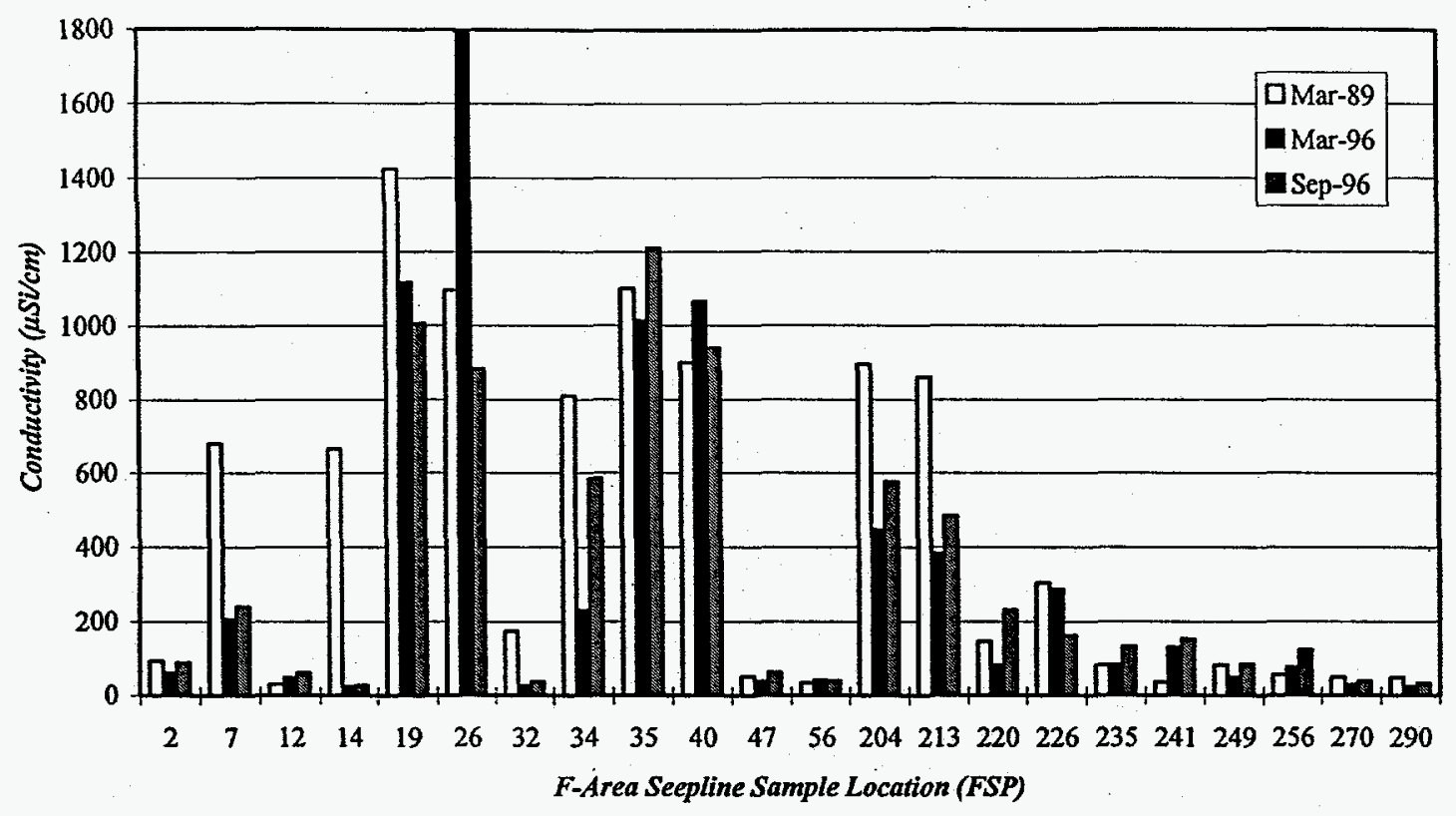

Figure 9. Comparison of Conductivity Measurements for Selected F-Area Seepline Locations

)

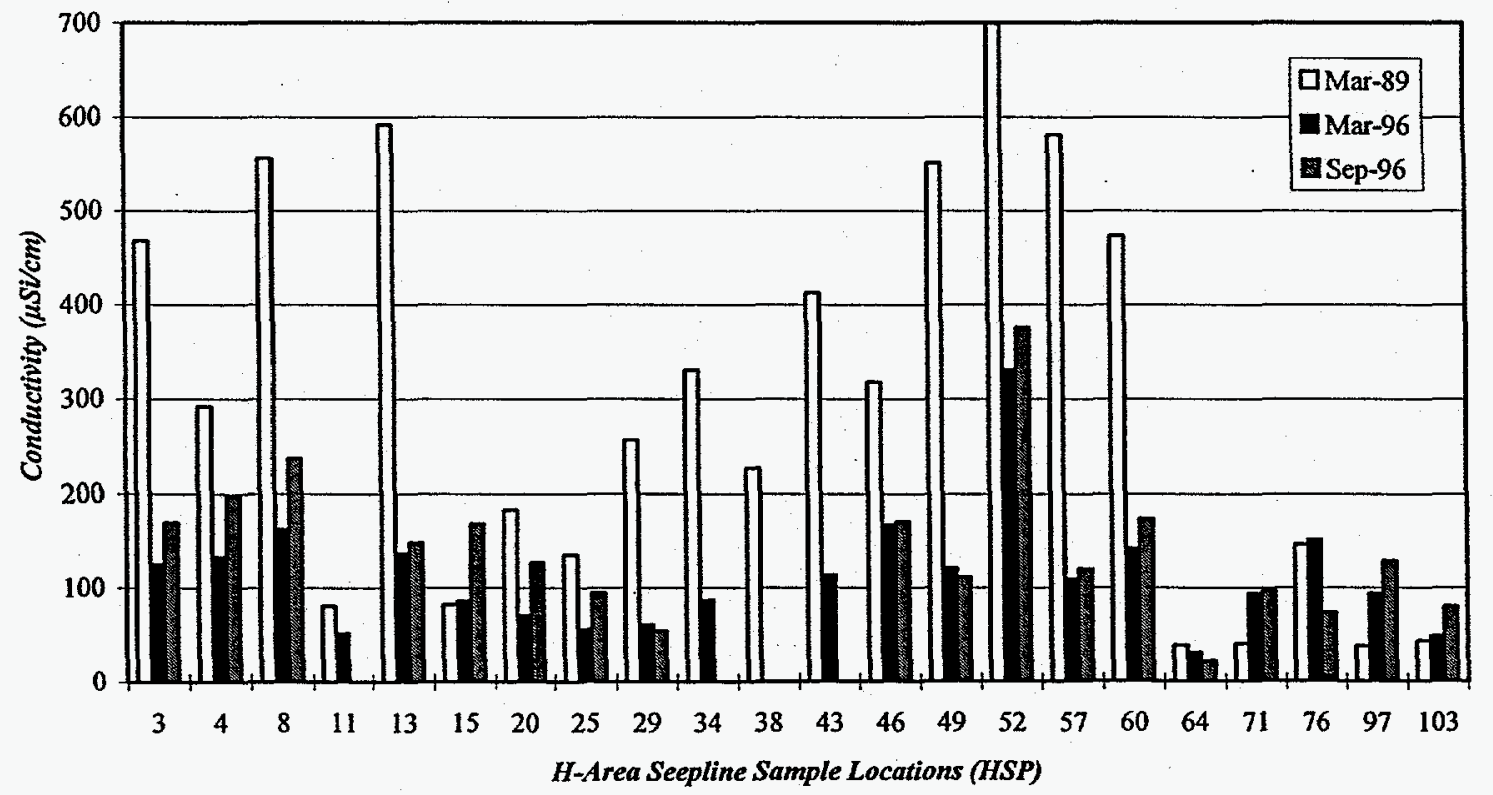

Figure 10. Comparison of Conductivity Measurements for Selected H-Area Seepline Locations. 


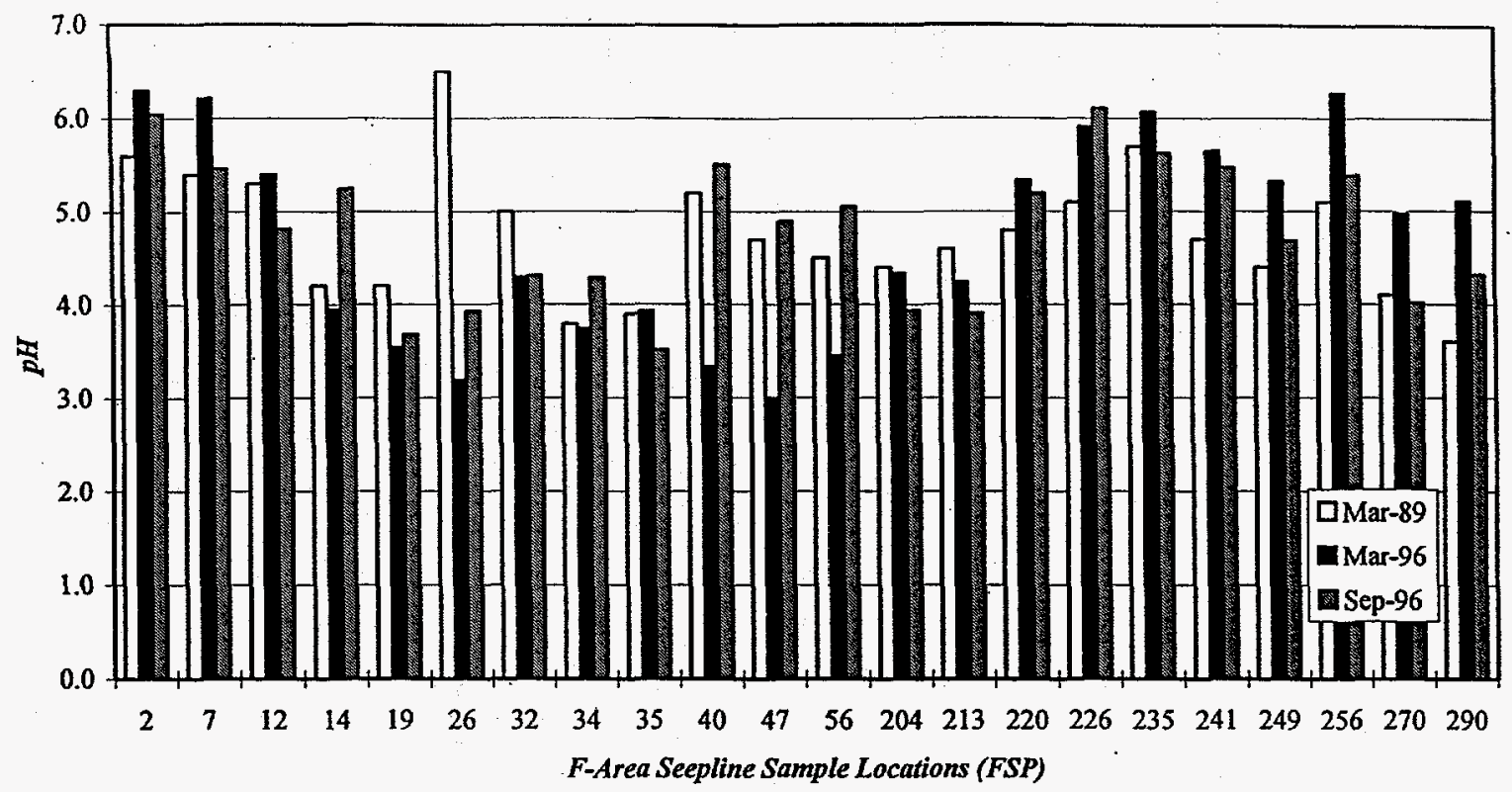

Figure 11. Comparison of $\mathrm{pH}$ Measurements for Selected F-Area Seepline Locations
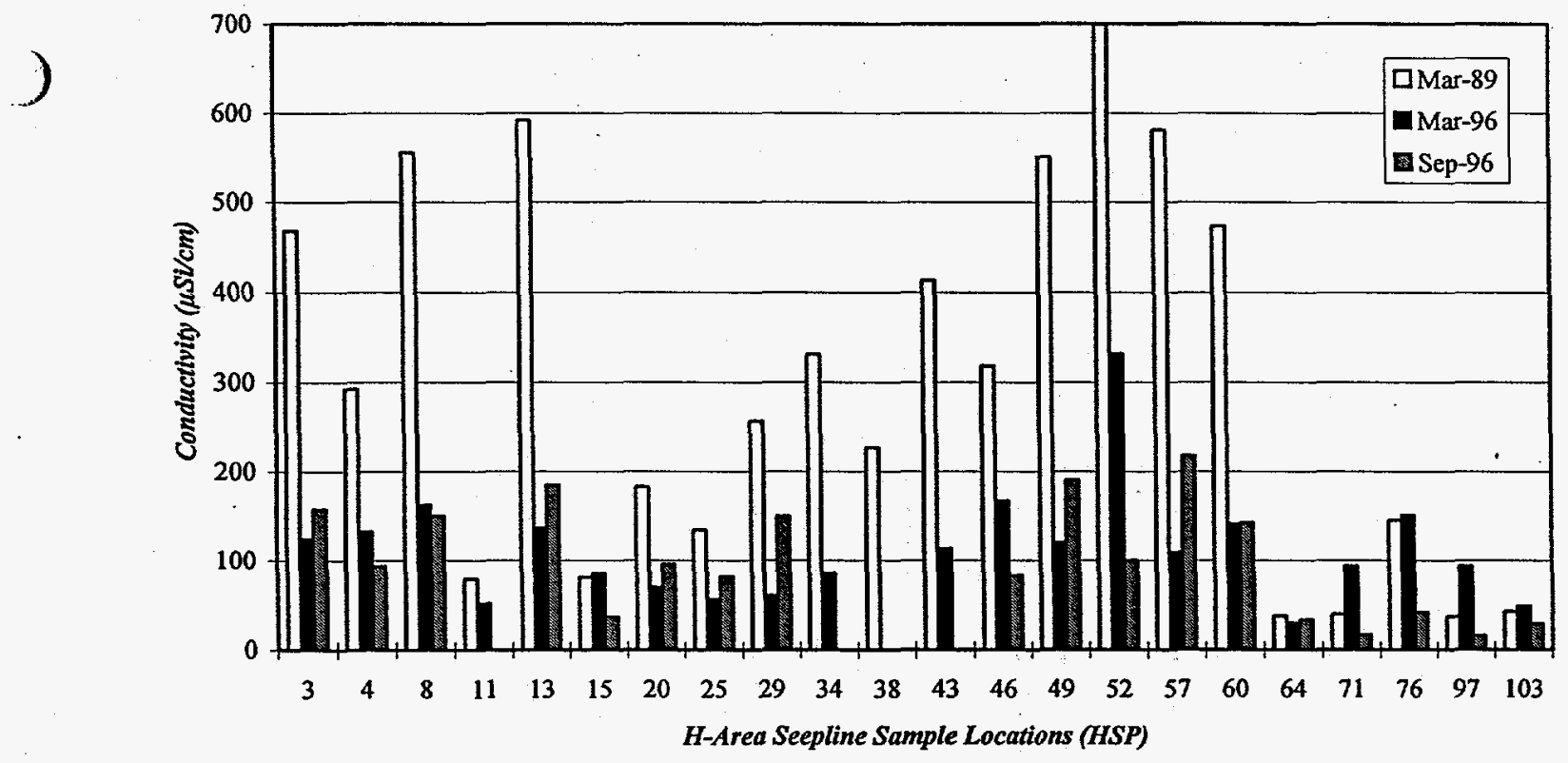

Figure 12. Comparison of $\mathrm{pH}$ Measurements for Selected H-Area Locations 
Results of the Tritium Survey of Fourmile Branch and its Seeplines in the F and H Areas of SRS: September 1996

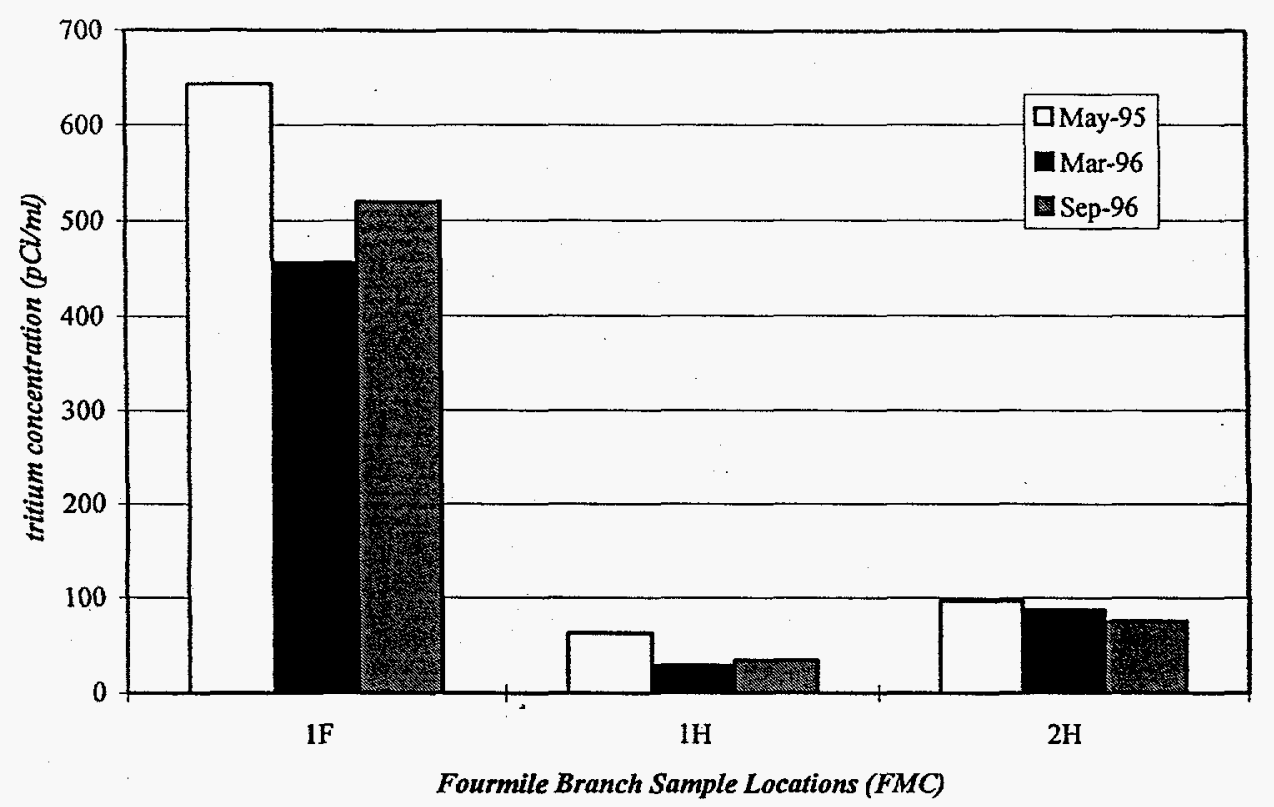

Figure 13. Comparison of Tritium Concentrations for Selected Fourmile Branch Locations

)

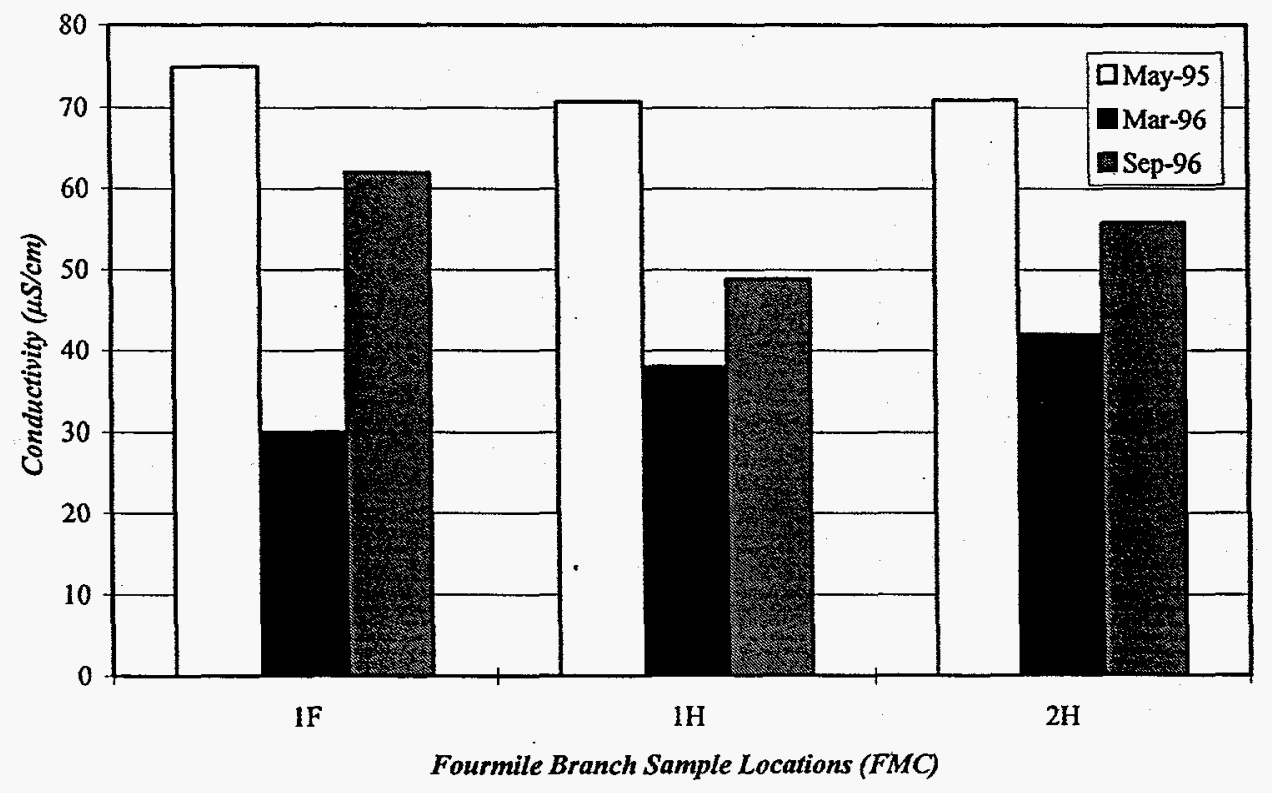

Figure 14. Comparison of Conductivity Measurements for Selected Fourmile Branch Locations 


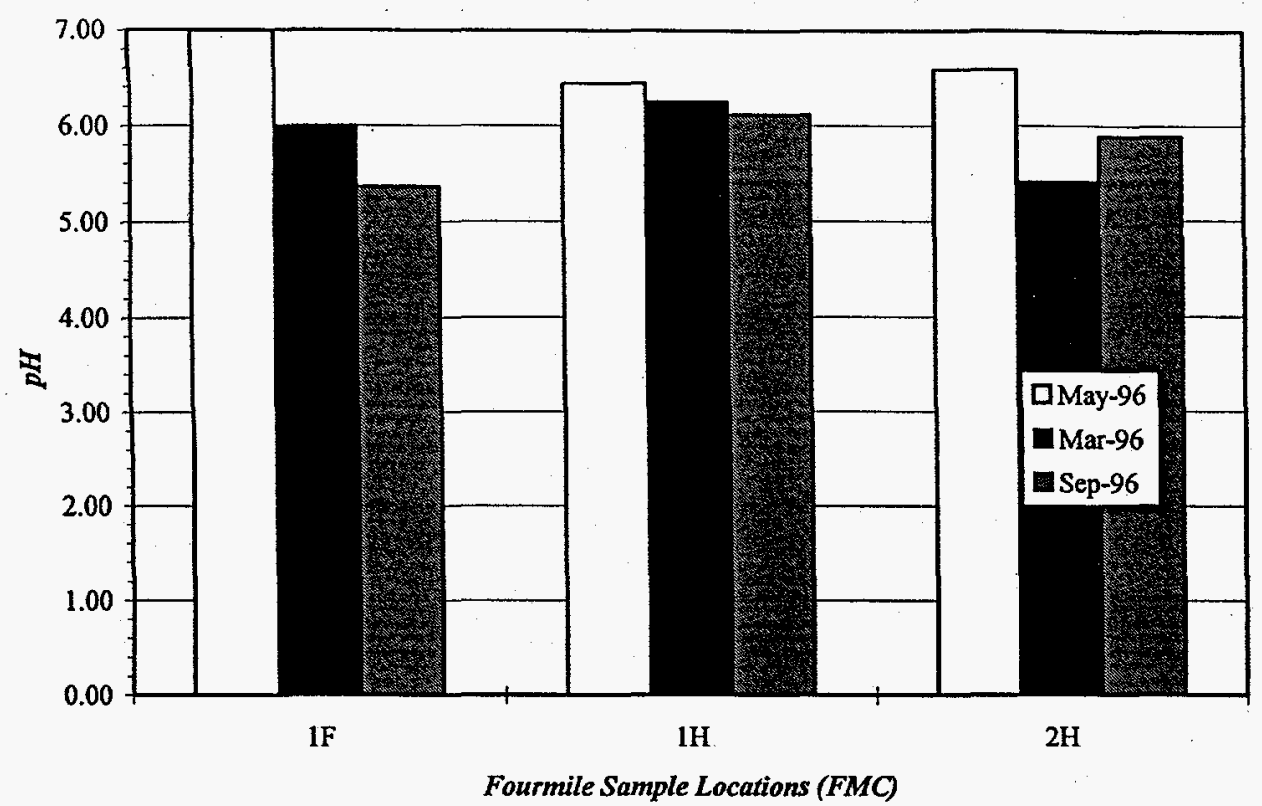

Figure 15. Comparison of $\mathrm{pH}$ Measurements for Selected Fourmile Branch Locations

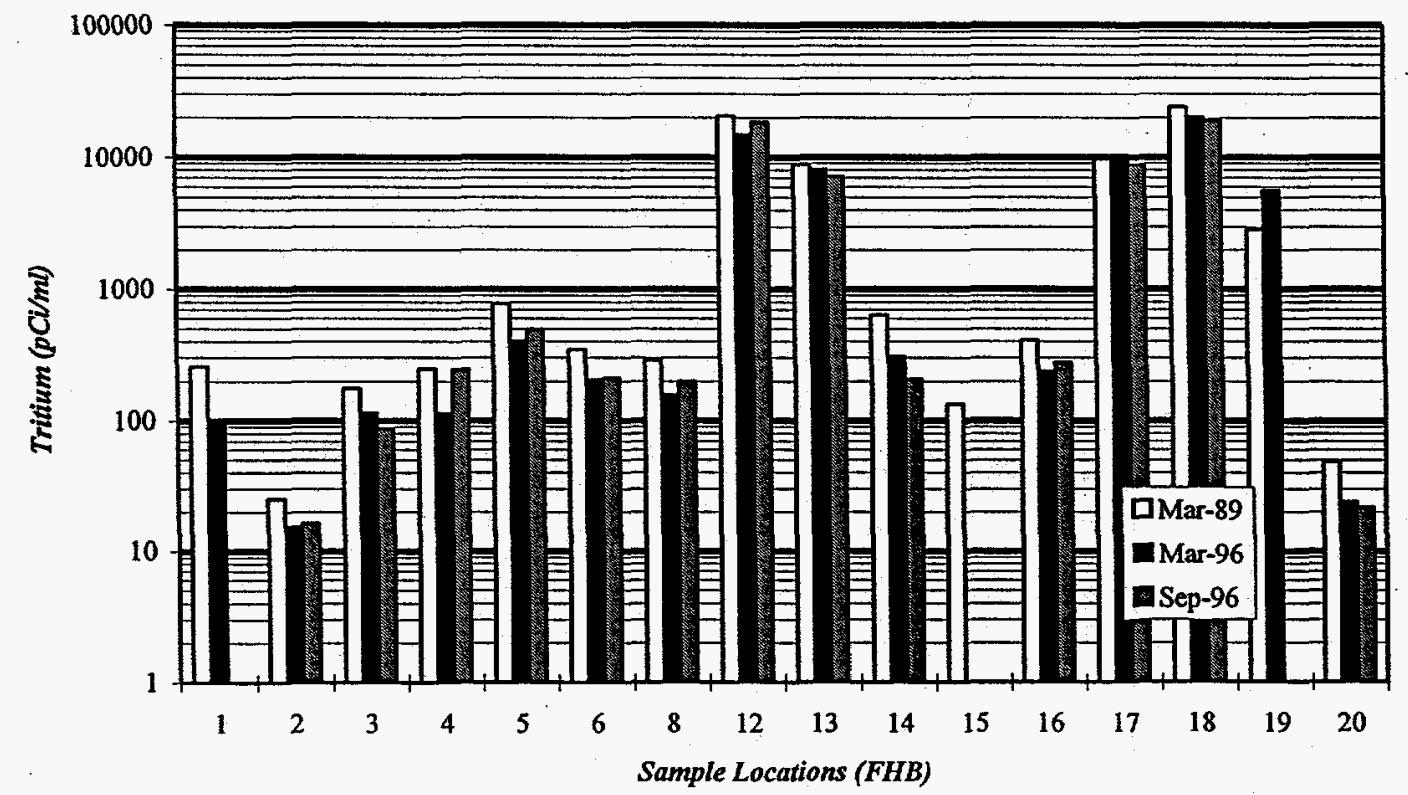

Figure 16. Comparison of Tritium Concentrations for Selected Locations on the Seepline South of 643-E 


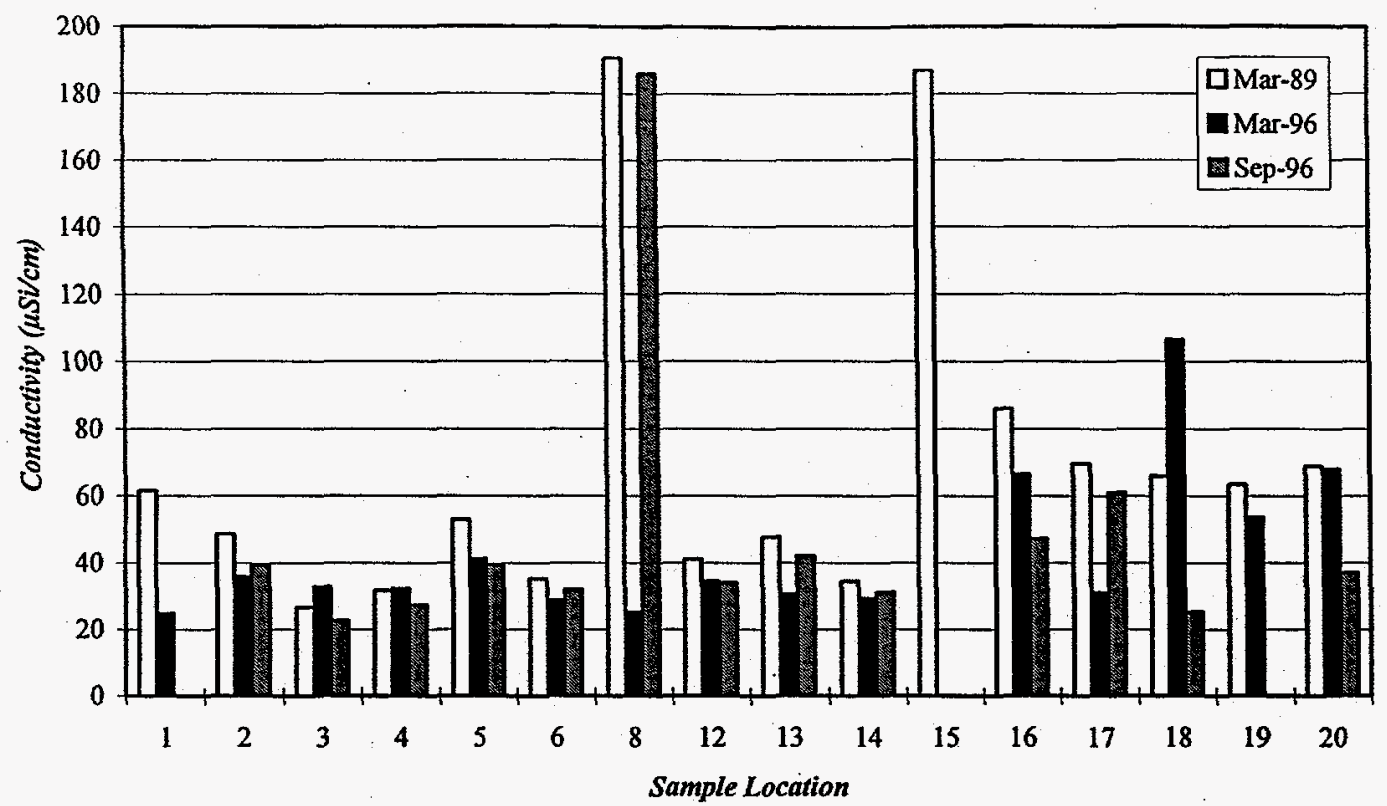

Figure 17. Comparison of Conductivity Concentrations for Selected Locations on the Seepline South of 643-E

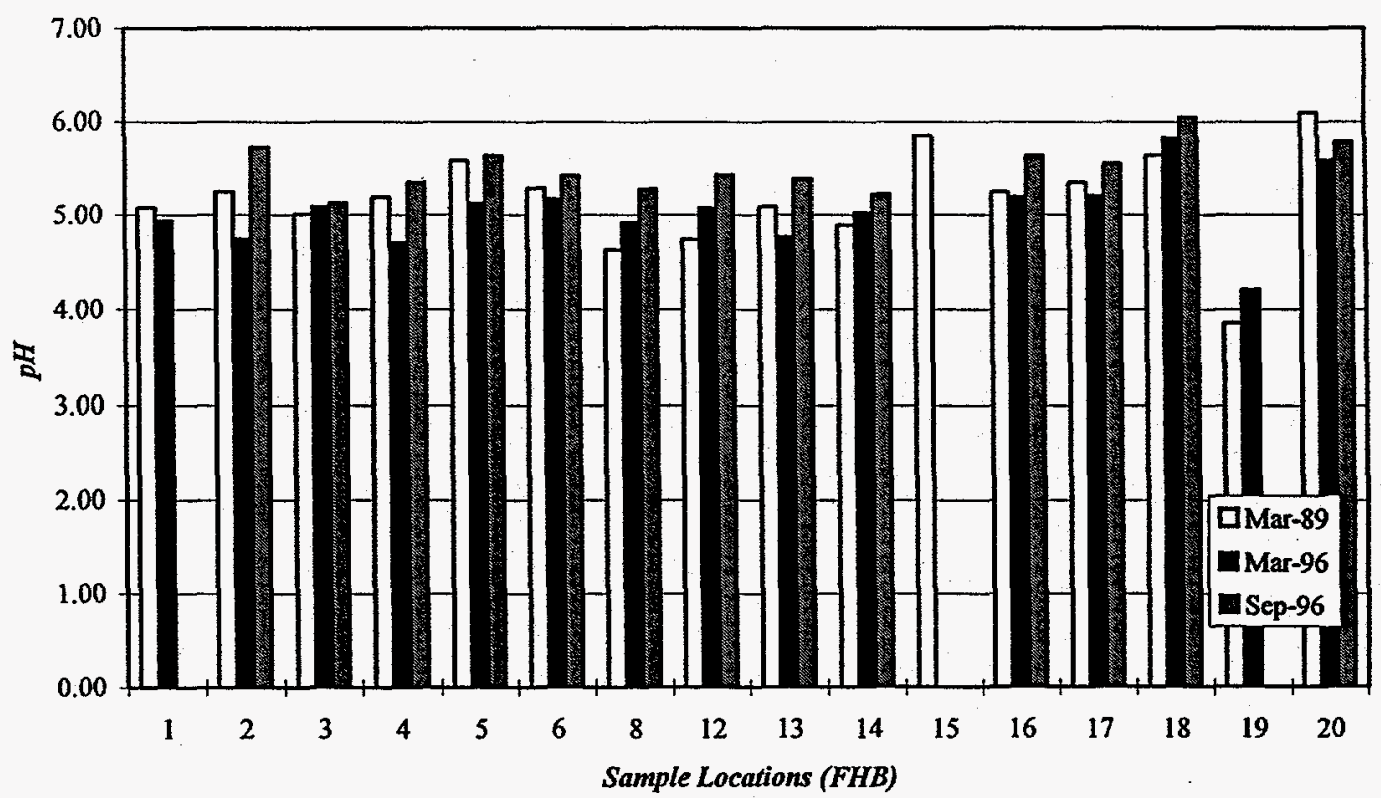

Figure 18. Comparison of pH Concentrations for Selected Locations on the Seepline South of 643-E 


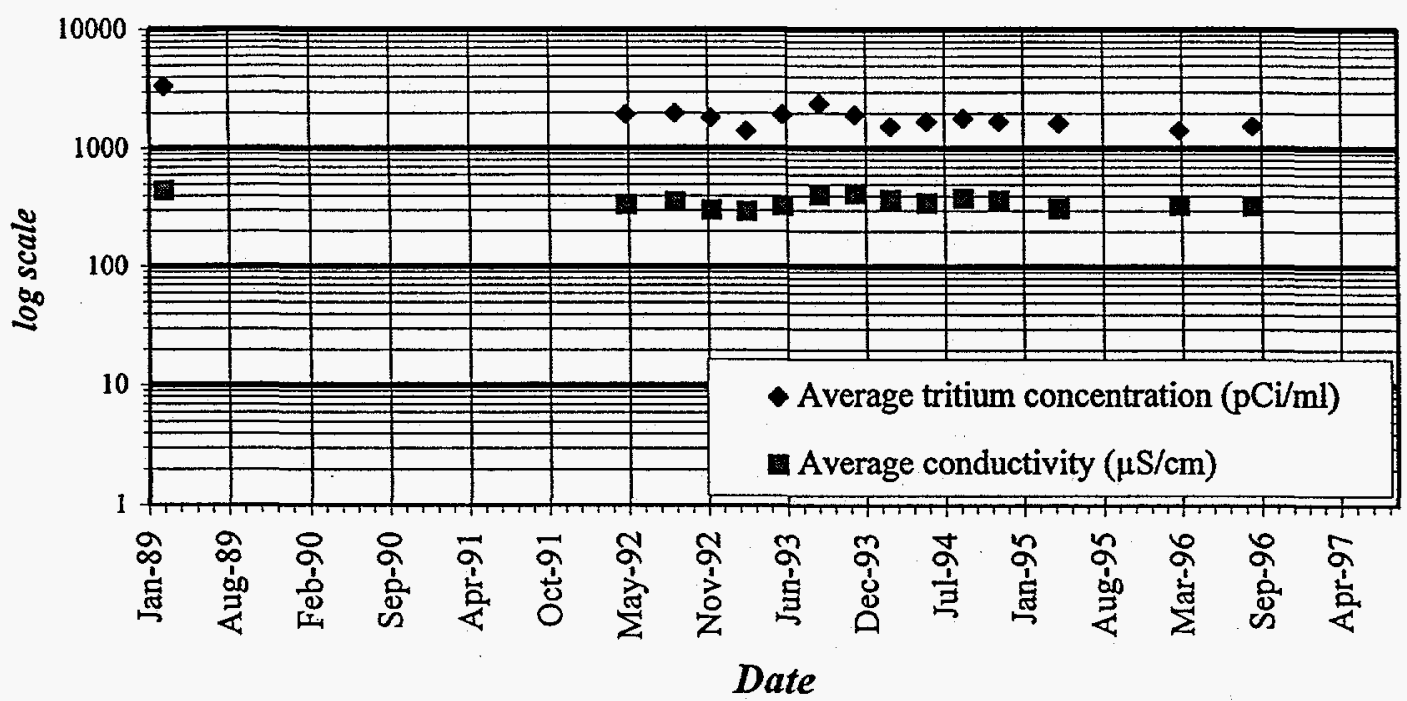

Figure 19. Tritium and Conductivity Trends for F-Area Seepline. Each point represents the mean value of a sampling event.

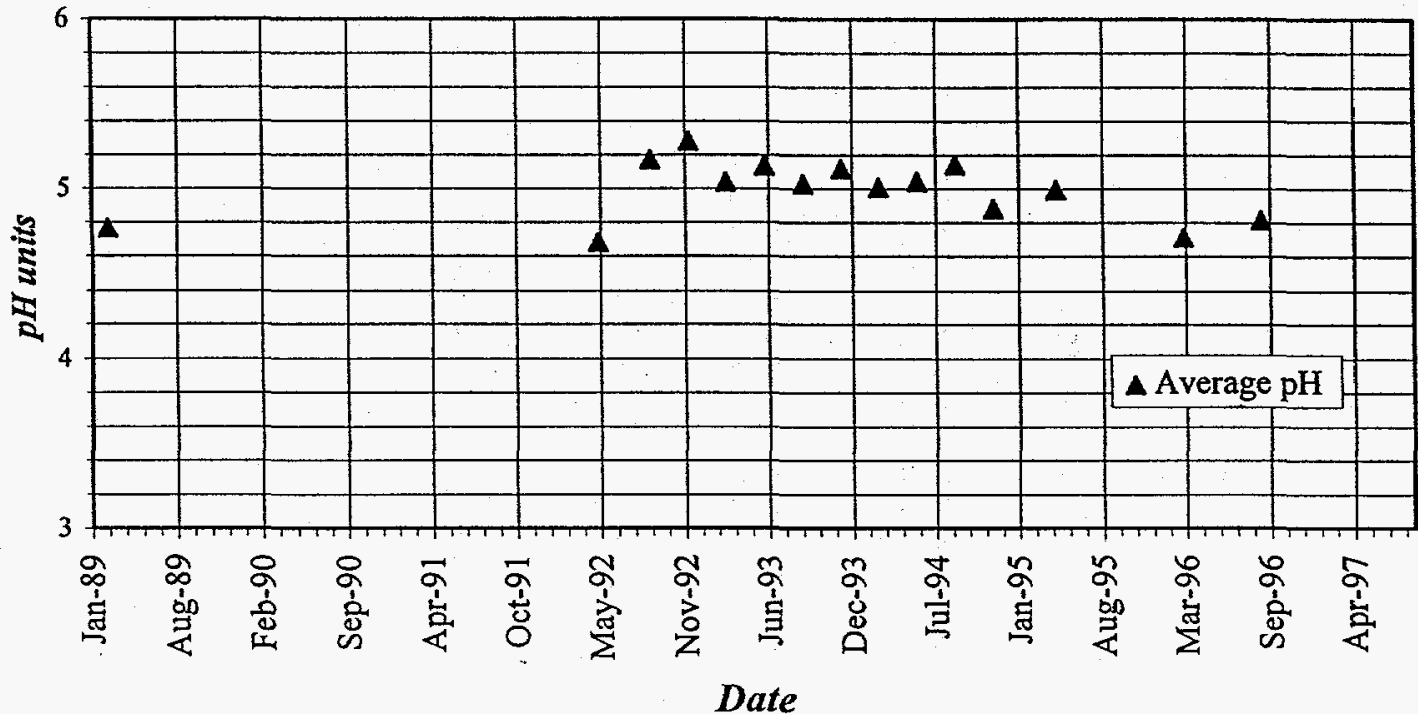

Figure 20. $\mathrm{pH}$ treads for the $\mathrm{F}$-Area Seepline. Each point represents the mean value of a sampling event. 
Results of the Tritium Survey of Fourmile Branch and its Seeplines in the F and H Areas of SRS: September 1996

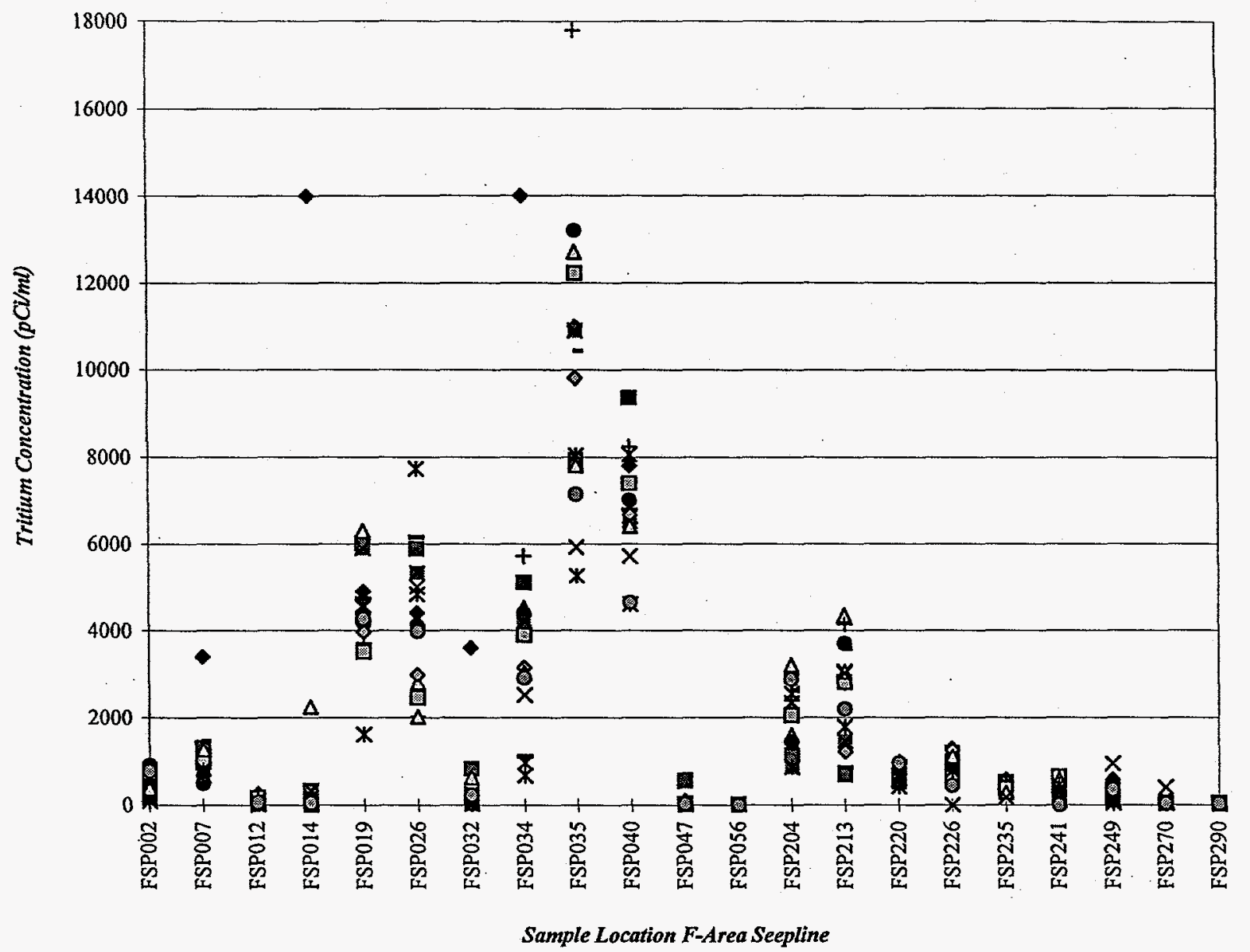

Figure 21. Scatter plot of tritium concentrations for F-Area Seepline (1989-1996)

Plot shows distribution of tritium throughout the entire sampling period. 


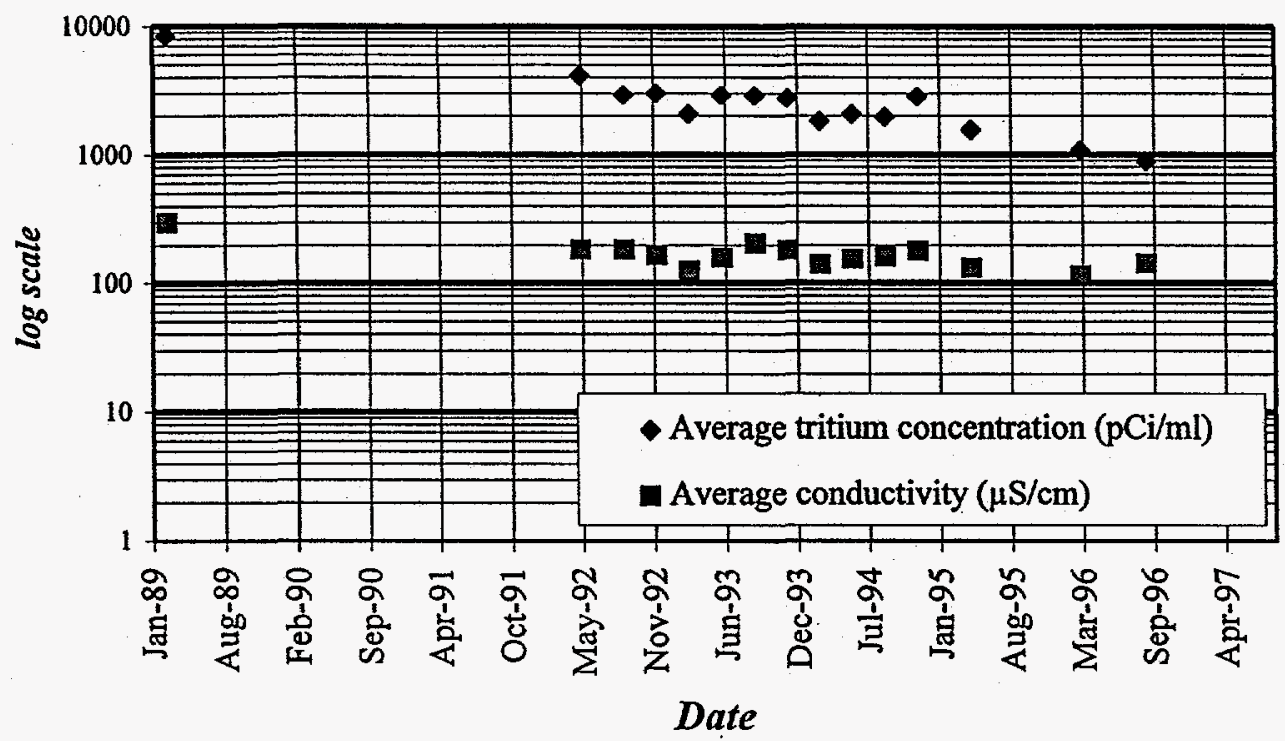

Figure 22. Tritium and conductivity trends for H-Area Seepline. Each point represents the mean value of a sampling event.

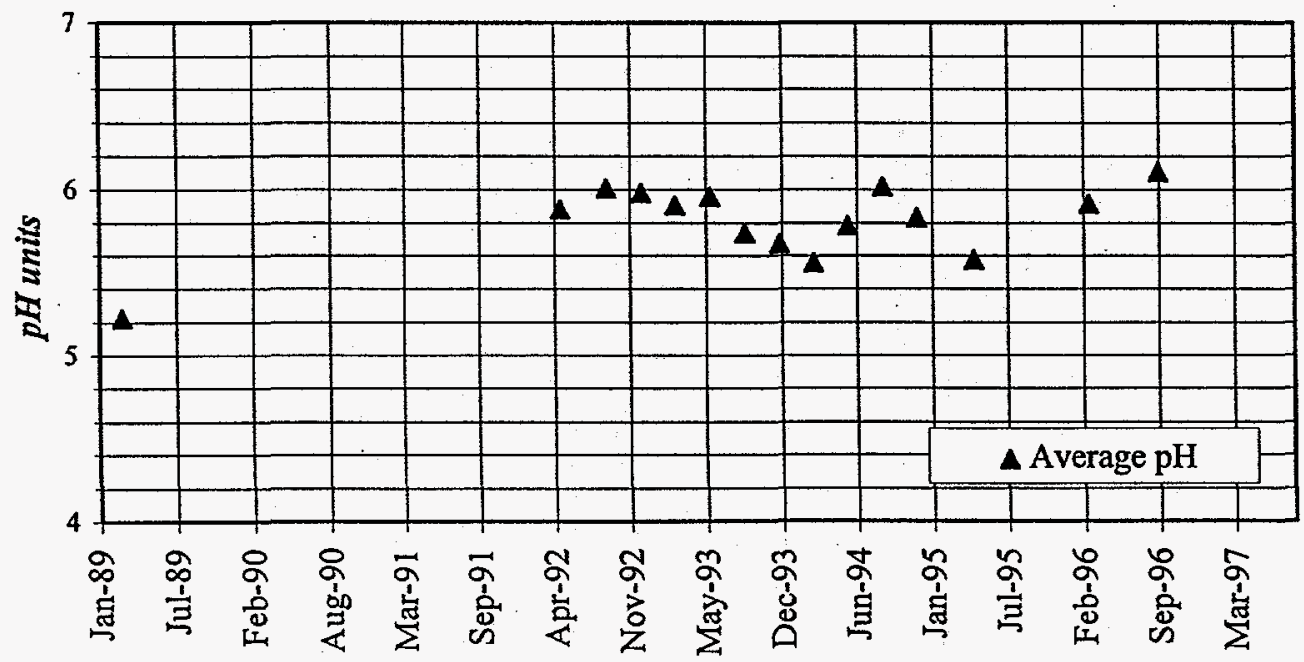

\section{Date}

Figure 23. $\quad \mathrm{pH}$ trends for the H-Area Seepline. Each point represents the mean pH value of a sampling event. 


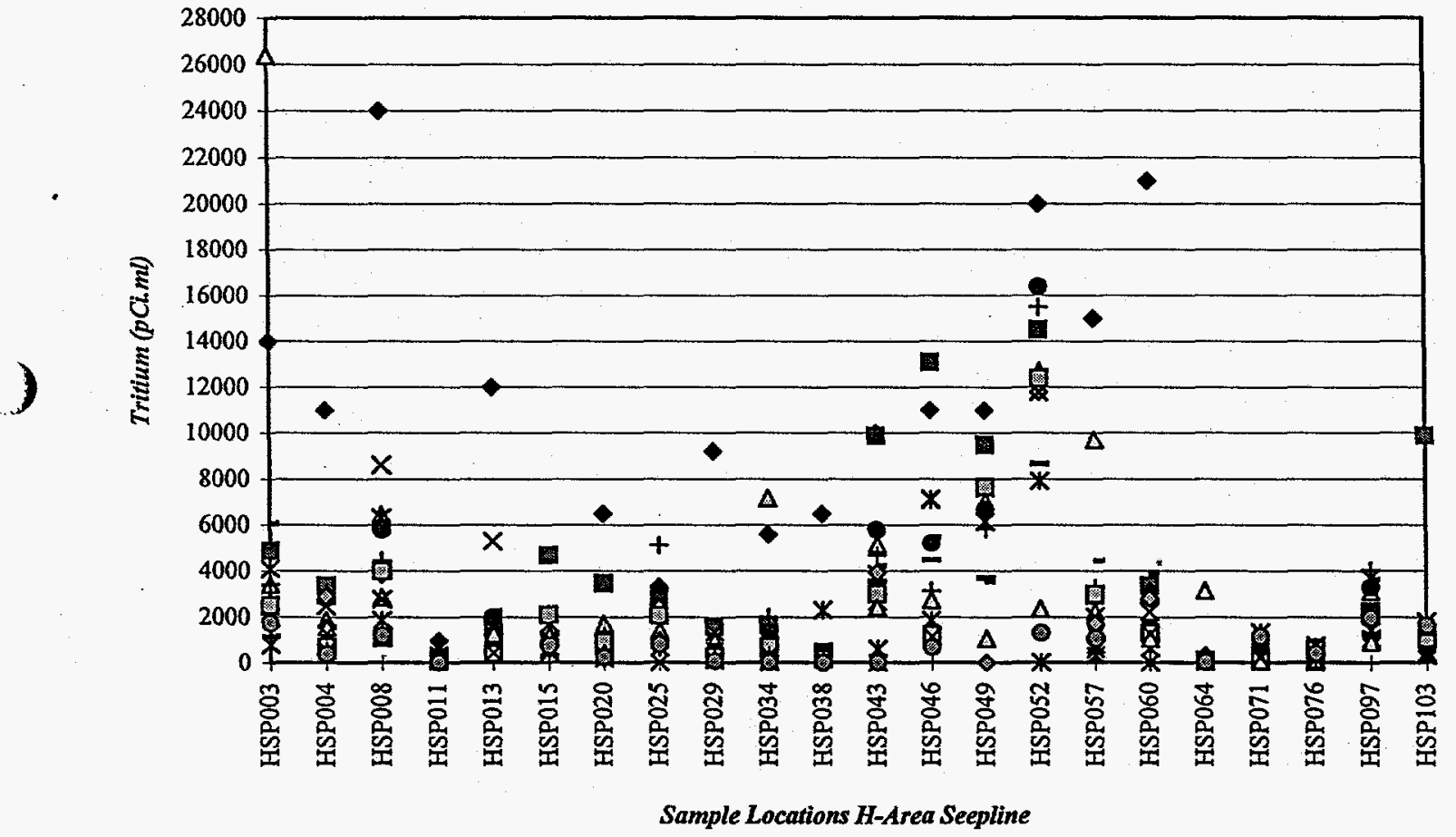

Figure 24. Scatter plot of tritium concentrations for the H-Area Seepline (1989-1996)

Plot shows distribution of tritium throughout the entire sampling period. 


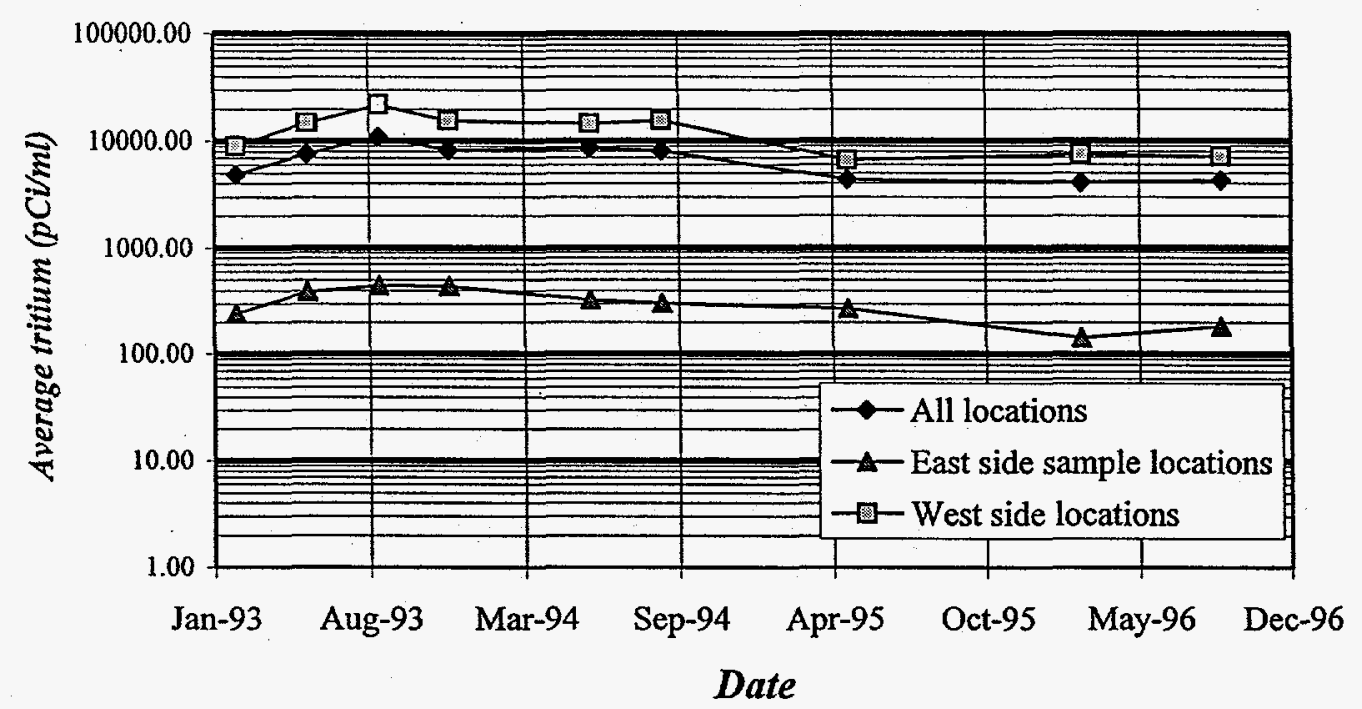

Figure 25. Comparison of tritium concentrations for Seepline below 643-E. Each point represents the mean value of a sampling event.

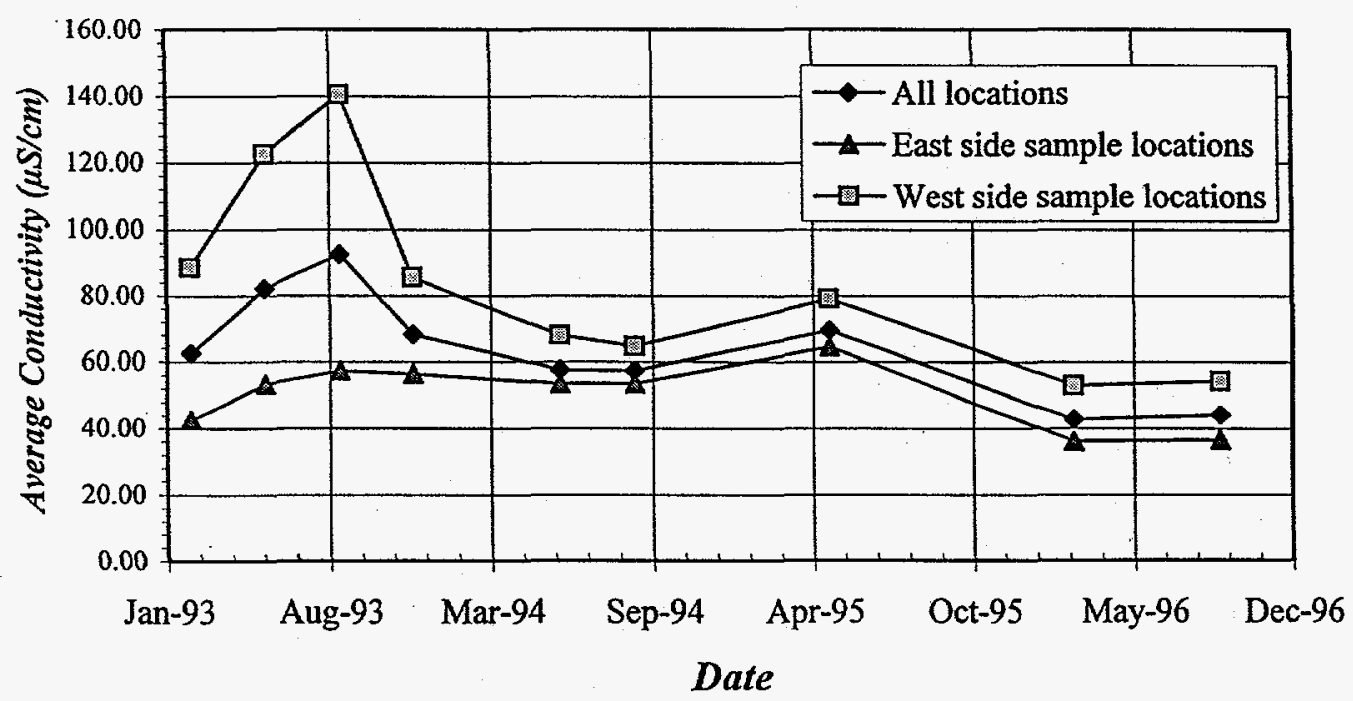

Figure 26. Comparison of conductivity concentrations for the Seepline below 643-E. Each point represents the mean value of a sampling event. 


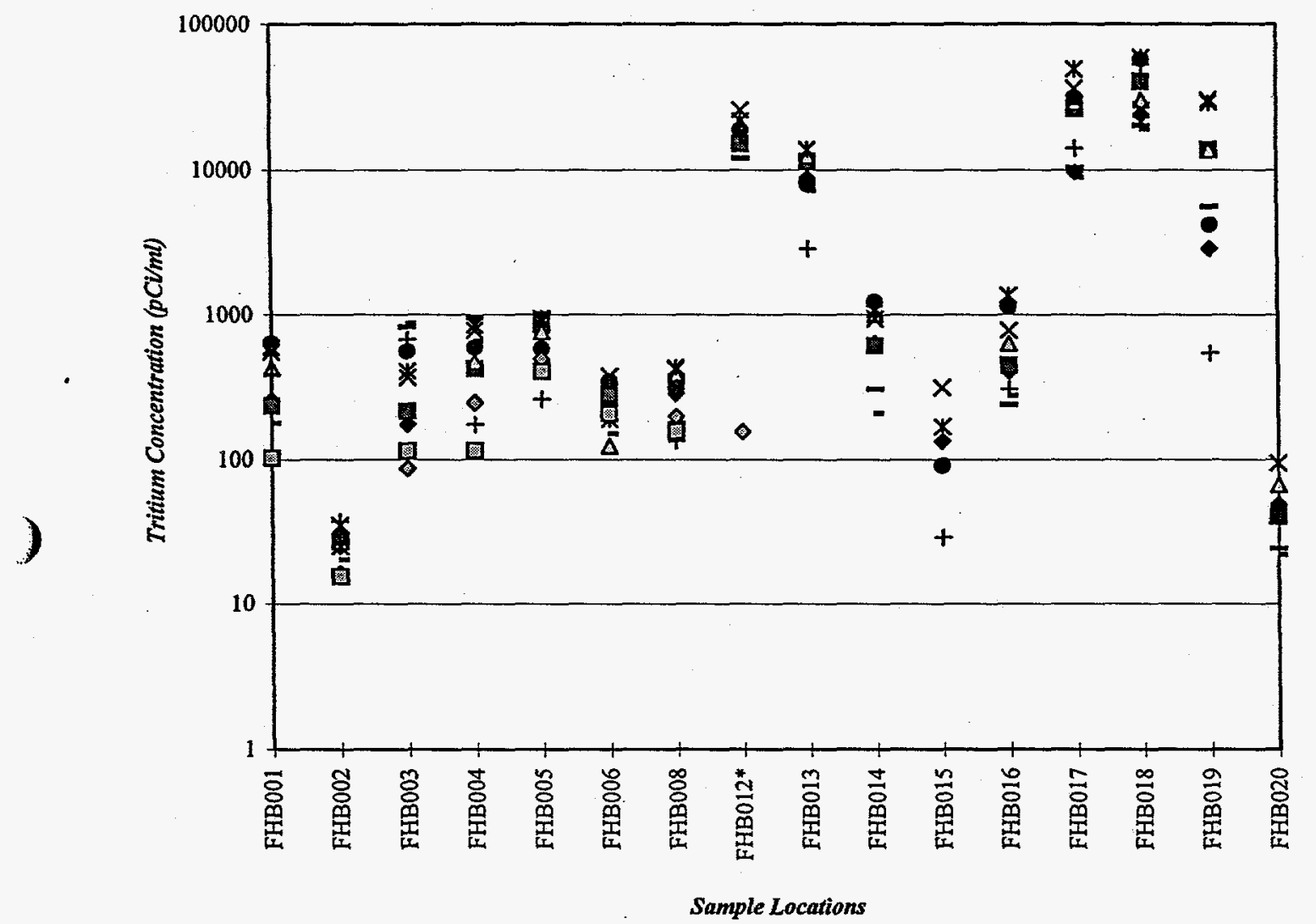

Figure 27. Scatter plot of tritium concentrations for the seepline below 643E, (1992-1996)

Plot shows distribution of tritium throughout the entire sampling period.

* Stream sample location 


\section{FMC001F}

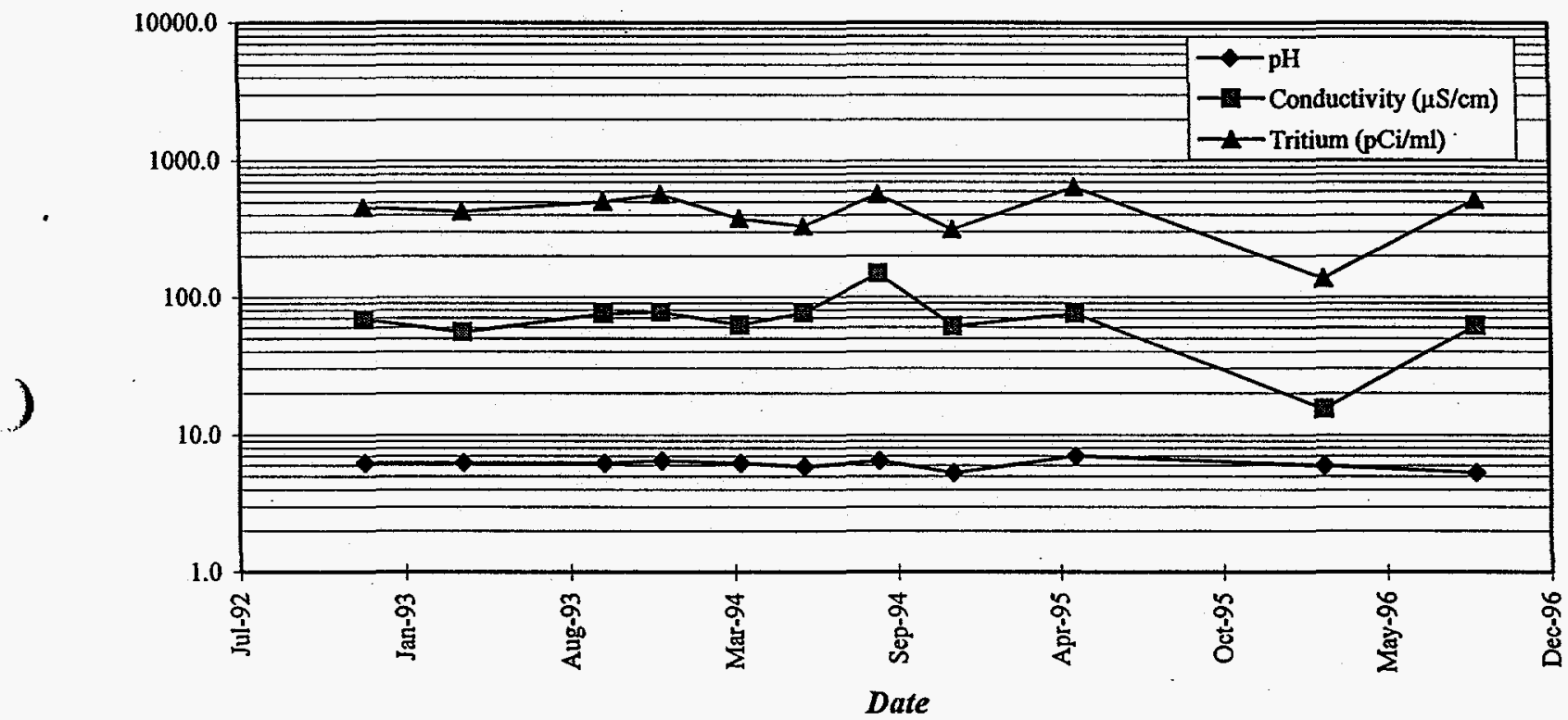

Figure 28. Tritium, conductivity, and pH measurements for samples location FMC001F (Fourmile Branch) 
Results of the Tritium Survey of Fourmile Branch and

its Seeplines in the F and H Areas of SRS: September 1996

\section{FMCOO1H}

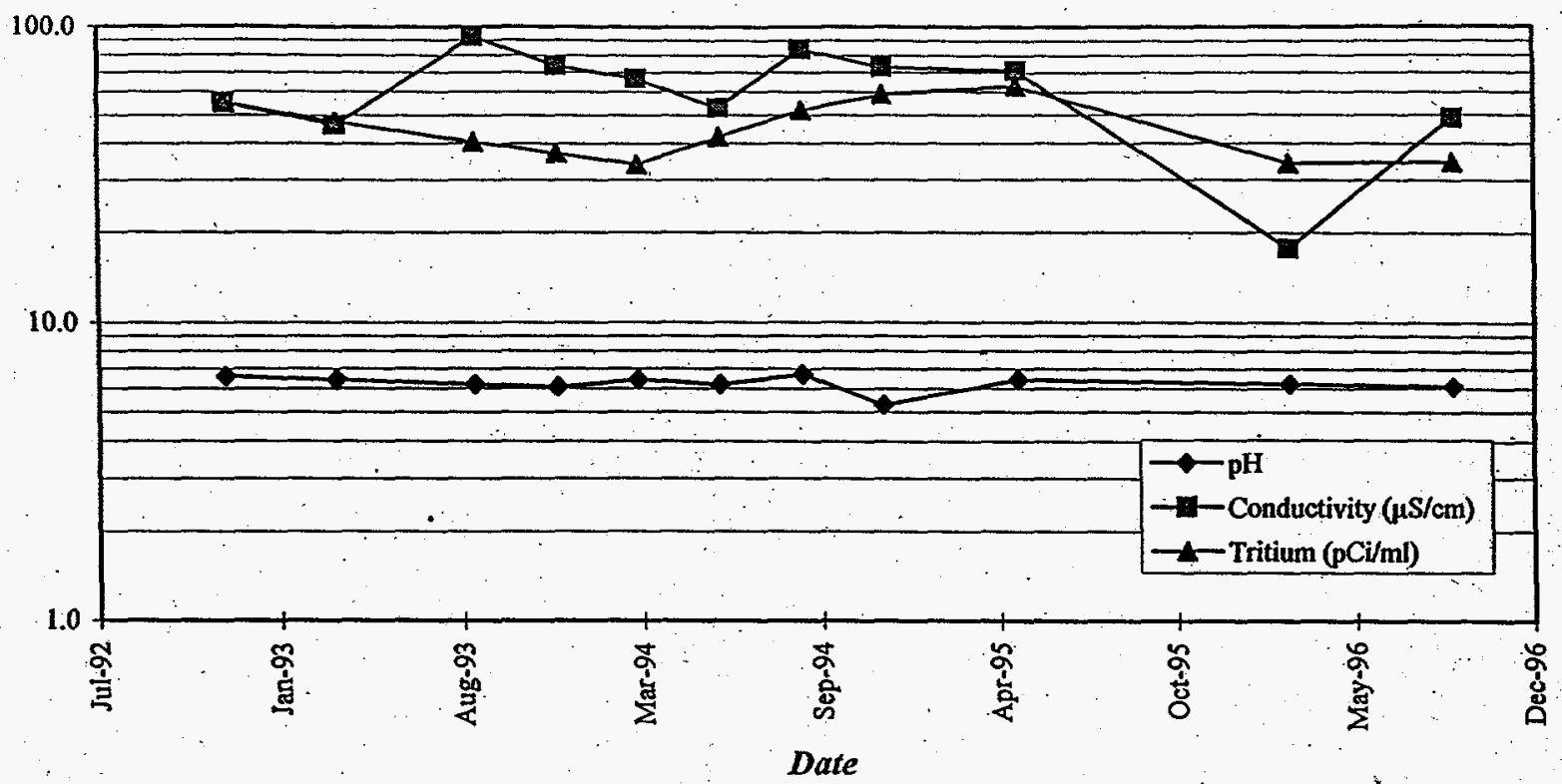

Figure 29. Tritium, conductivity, and $\mathrm{pH}$ measurements for samples location FMC001H (Fourmile Branch)

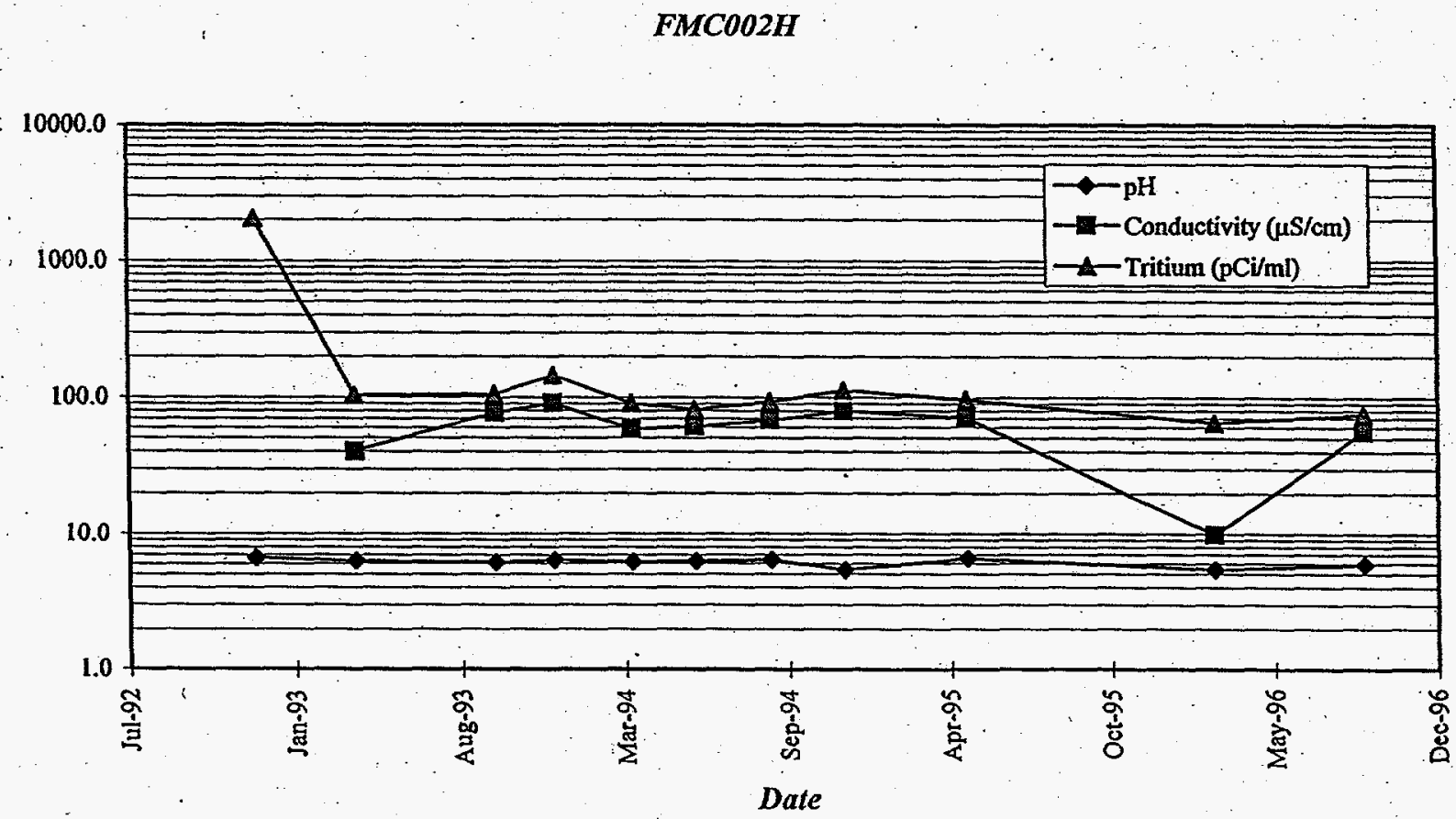

Figure 30. Tritium, conductivity, and $\mathrm{pH}$ measurements for samples location FMCO02H (Fourmile Branch) 
Table 1. Comparison of 1995/1996 Monthly Rainfall to the Long Term Average Rainfall From the F-Area Weather Station

\begin{tabular}{|c|c|c|c|}
\hline & & & Rainfall $(\mathrm{cm}) / F-$ Area \\
\hline Month: & & Oct $1995-$ Sept 1996 & Long-Term Rainfall, (1961-1994) \\
\hline Oct & 95 & 5.88 & $\therefore 7.80$ \\
\hline Nov & 95 & 5.41 & 7.12 \\
\hline & - & & . \\
\hline Dec & 95 & 9.91 & 8.97 \\
\hline & . & & \\
\hline Jan & 96 & 7.82 & 11.14 \\
\hline- & & & $\cdot$ \\
\hline Feb & 96 & 5.28 & 10.74 \\
\hline & . & & \\
\hline Mar & 96. & 17.30 & 12.62 \\
\hline & & & \\
\hline April & 96 & 4.30 & 8.01 \\
\hline & $\cdot$ & & \\
\hline May & 96. & 6.10 & 9.31 \\
\hline . & & & $\therefore$ \\
\hline June & 96. & 11.66 & 11.77 \\
\hline & & & \\
\hline July & 96 & 14.10 & 13.97 \\
\hline & & & \\
\hline Aug & 96 & 26.92 & 14.56 \\
\hline . & : & $\therefore$ & 1. \\
\hline Sept & 96 & 7.98 & 8.77 \\
\hline
\end{tabular}


Table 2. Comparison of F-Area Seepline Measurements for Tritium, Conductivity, and $\mathrm{pH}$ for the March 1989, March 1996, and September 1996 Sampling Events.

\begin{tabular}{|c|c|c|c|c|c|c|c|c|c|}
\hline & \multicolumn{3}{|c|}{ Tritium (pCi/mI) } & \multicolumn{2}{c|}{ Conductivity $(\mu \mathrm{S} / \mathrm{cm})$} & \multicolumn{3}{c|}{$\boldsymbol{H}$ (-log $\boldsymbol{H})$} \\
\hline Location & Mar-89 & Mar-96 & Sep-96 & Mar-89 & Mar-96 & Sep-96 & Mar-89 & Mar-96 & Sep-96 \\
\hline 2 & 520 & 612.5 & 779 & 95 & 63 & 90 & 5.6 & 6.3 & 6.1 \\
\hline 7 & 3400 & 809 & 1010 & 681 & 208 & 241 & 5.4 & 6.2 & 5.5 \\
\hline 12 & 260 & 19.1 & 70 & 30 & 49 & 62 & 5.3 & 5.4 & 4.8 \\
\hline 14 & 14000 & 10.8 & 51 & 666 & 26 & 28 & 4.2 & 4.0 & 5.3 \\
\hline 19 & 4900 & 4530 & 4270 & 1424 & 1117 & 1007 & 4.2 & 3.5 & 3.7 \\
\hline 26 & 4400 & 7740 & 3980 & 1095 & 1799 & 884 & 6.5 & 3.2 & 3.9 \\
\hline 32 & 3600 & 32.7 & 232 & 174 & 27 & 38 & 5.0 & 4.3 & 4.3 \\
\hline 34 & 14000 & 677 & 2910 & 810 & 232 & 585 & 3.8 & 3.8 & 4.3 \\
\hline 35 & 11000 & 5260 & 7150 & 1100 & 1014 & 1210 & 3.9 & 3.9 & 3.5 \\
\hline 40 & 7800 & 4600 & 4640 & 900 & 1066 & 940 & 5.2 & 3.3 & 5.5 \\
\hline 47 & 100 & 15.3 & 20 & 52 & 40 & 63 & 4.7 & 3.0 & 4.9 \\
\hline 56 & 19 & 7.38 & 7 & 34 & 42 & 41 & 4.5 & 3.5 & 5.1 \\
\hline 204 & 3000 & 2560 & 2880 & 895 & 449 & 576 & 4.4 & 4.3 & 3.9 \\
\hline 213 & 2800 & 1790 & 2200 & 860 & 384 & 486 & 4.6 & 4.2 & 3.9 \\
\hline 220 & 560 & 698 & 955 & 147 & 84 & 232 & 4.8 & 5.3 & 5.2 \\
\hline 226 & 1300 & 776 & 443 & 306 & 288 & 162 & 5.1 & 5.9 & 6.1 \\
\hline 235 & 580 & 290 & 176 & 84 & 84 & 134 & 5.7 & 6.1 & 5.6 \\
\hline 241 & 560 & 456 & dry & 36 & 133 & 154 & 4.7 & 5.7 & 5.5 \\
\hline 249 & 580 & 67.8 & 345 & 84 & 50 & 86 & 4.4 & 5.3 & 4.7 \\
\hline 256 & 400 & 307 & 285 & 56 & 78 & 126 & 5.1 & 6.3 & 5.4 \\
\hline 270 & 40 & 35.5 & 42 & 50 & 31 & 39 & 4.1 & 5.0 & 4.0 \\
\hline 290 & 35 & 24.7 & 35 & 49 & 25 & 34 & 3.6 & 5.1 & 4.3 \\
\hline
\end{tabular}


Table 3. Comparison of H-Area Seepline Measurements for Tritium, Conductivity, and $\mathrm{pH}$ for the March 1989, March 1996, and September 1996 Sampling Events.

\begin{tabular}{|c|c|c|c|c|c|c|c|c|c|}
\hline & \multicolumn{3}{|c|}{ Tritium $(p C i / m l)$} & \multicolumn{3}{c|}{ Conductivity $(\mu$ S/cm)@25deg C } & \multicolumn{3}{c|}{$p H$ (-Iog H) } \\
\hline Location & Mar-89 & Mar-96 & Sep-96 & Mar-89 & Mar-96 & Sep-96 & Mar-89 & Mar-96 & Sep-96 \\
\hline 3 & 14000 & 780 & 1740 & 468 & 125 & 170 & 5.2 & 6.3 & 6.3 \\
\hline 4 & 11000 & 545 & 386 & 292 & 133 & 198 & 5.8 & 6.6 & 6.4 \\
\hline 8 & 24000 & 1865 & 1190 & 556 & 163 & 237 & 5.7 & 6.4 & 6.7 \\
\hline 11 & 960 & 148 & dry & 80 & 52 & dry & 5.1 & 5.6 & dry \\
\hline 13 & 12000 & 1260 & 435 & 592 & 137 & 148 & 6.2 & 6.5 & 6.3 \\
\hline 15 & 1000 & 561 & 776 & 82 & 86 & 168 & 5.2 & 5.6 & 6.0 \\
\hline 20 & 6500 & 180 & 228 & 183 & 71 & 127 & 6.2 & 5.7 & 5.9 \\
\hline 25 & 3300 & 655 & 799 & 135 & 57 & 94 & 4.7 & 6.0 & 5.9 \\
\hline 29 & 9200 & 98 & 70 & 257 & 61 & 54 & 5.2 & 5.3 & 5.9 \\
\hline 34 & 5600 & 341 & dry & 331 & 86 & dry & 5.8 & 6.0 & dry \\
\hline 38 & 6500 & 2310 & dry & 227 & dry & dry & 4.9 & dry & dry \\
\hline 43 & 10000 & 603 & dry & 413 & 114 & dry & 5.3 & 6.4 & dry \\
\hline 46 & 11000 & 1870 & 663 & 318 & 167 & 170 & 5.5 & 6.3 & 6.0 \\
\hline 49 & 11000 & 7660 & 1060 & 551 & 121 & 112 & 4.4 & 5.5 & 5.8 \\
\hline 52 & 20000 & 24 & 1310 & 699 & 332 & 375 & 4.1 & 5.8 & 5.9 \\
\hline 57 & 15000 & 334 & 1080 & 581 & 110 & 120 & 5.5 & 5.6 & 6.0 \\
\hline 60 & 21000 & 1260 & dry & 473 & 142 & 174 & 5.9 & 5.9 & 6.1 \\
\hline 64 & 320 & 20 & 20 & 38 & 30 & 22 & 4.7 & 5.1 & 5.8 \\
\hline 71 & 450 & 1340 & 1160 & 40 & 94 & 96 & 5.1 & 6.5 & 6.5 \\
\hline 76 & 400 & 152 & 410 & 146 & 151 & 74 & 5.7 & 6.7 & 6.7 \\
\hline 97 & 1100 & 1440 & 1980 & 37 & 94 & 129 & 4.3 & 5.7 & 6.3 \\
\hline 103 & 510 & 357 & 1660 & 43 & 48 & 80 & 4.4 & 5.1 & 5.6 \\
\hline
\end{tabular}

Table 4. Comparison of Fourmile Branch Stream Measurements for Tritium, Conductivity, and pH for the May 1995, March 1996, and September 1996 Sampling Events.

\begin{tabular}{|c|c|c|c|c|c|c|c|c|c|}
\hline & \multicolumn{3}{|c|}{ Tritium (pCi/ml } & \multicolumn{3}{c|}{ Conductivity $(\mu$ S/cm) } & \multicolumn{3}{c|}{$p H$ (-log H) } \\
\hline Location & May-95 & Mar-96 & Sep-96 & May-95 & Mar-96 & Sep-96 & May-95 & Mar-96 & Sep-96 \\
\hline IF & 643 & 456 & 520 & 75 & 30 & 62 & 6.99 & 6.00 & 5.36 \\
\hline IH & 63 & 29 & 35 & 71 & 38 & 49 & 6.44 & 6.25 & 6.12 \\
\hline $2 H$ & 97 & 88 & 76 & 71 & 42 & 56 & 6.59 & 5.41 & 5.89 \\
\hline
\end{tabular}


Table 5. Comparison of 643-E Seepline Measurements for Tritium, Conductivity, and pH for the May 1995, March 1996, and September 1996 Sampling Events.

\begin{tabular}{|c|r|c|c|c|c|c|c|c|c|}
\hline & \multicolumn{3}{|c|}{ Tritium $(\mathrm{pCi} \mathrm{mI})$} & \multicolumn{3}{c|}{ Conductivity $(\mu \mathrm{S} / \mathrm{cm})$} & \multicolumn{3}{c|}{$p H(-\log \boldsymbol{H})$} \\
\hline Location & May-95 & Mar-96 & Sep-96 & May-95 & Mar-96 & Sep-96 & May-95 & Mar-96 & Sep-96 \\
\hline 1 & 258 & 102 & $\mathrm{dry}$ & 61 & 25 & $\mathrm{dry}$ & 5.1 & 4.9 & dry \\
\hline 2 & 25 & 15.4 & 16 & 49 & 36 & 47 & 5.3 & 4.8 & 5.7 \\
\hline 3 & 176 & 115 & 87 & 27 & 33 & 38 & 5.0 & 5.1 & 5.1 \\
\hline 4 & 249 & 115 & 247 & 32 & 32 & 18 & 5.2 & 4.7 & 5.4 \\
\hline 5 & 774 & 406 & 496 & 53 & 41 & 52 & 5.6 & 5.1 & 5.6 \\
\hline 6 & 344 & 207 & 211 & 35 & 29 & 34 & 5.3 & 5.2 & 5.4 \\
\hline 8 & 287 & 156.5 & 200 & 191 & 25 & 29 & 4.6 & 4.9 & 5.3 \\
\hline 12 & 20600 & 15000 & 18500 & 41 & 35 & 46 & 4.7 & 5.1 & 5.4 \\
\hline 13 & 8800 & 8120 & 7190 & 48 & 31 & 42 & 5.1 & 4.8 & 5.4 \\
\hline 14 & 639 & 307 & 209 & 34 & 29 & 33 & 4.9 & 5.0 & 5.2 \\
\hline 15 & 134 & dry & dry & 187 & dry & dry & 5.9 & dry & dry \\
\hline 16 & 407 & 240 & 278 & 86 & 66 & 80 & 5.3 & 5.2 & 5.6 \\
\hline 17 & 9660 & 10400 & 8830 & 70 & 31 & 42 & 5.4 & 5.2 & 5.6 \\
\hline 18 & 23900 & 20200 & 19100 & 66 & 106 & 74 & 5.6 & 5.8 & 6.1 \\
\hline 19 & 2870 & 5630 & dry & 63 & 54 & dry & 3.9 & 4.2 & dry \\
\hline 20 & 49 & 24.1 & 22 & 69 & 68 & 38 & 6.1 & 5.6 & 5.8 \\
\hline
\end{tabular}

Note: Location \#12 is a stream sample location.

Table 6. Average Tritium, Conductivity, and $\mathrm{pH}$ values for $\mathrm{F}$ and $\mathrm{H}$ Area Seeplines (March 1989-September 1996)

\begin{tabular}{|l|c|c|c||c|c|c|}
\hline & \multicolumn{3}{|c|}{ F Area Seepline-Average Values } & \multicolumn{3}{|c|}{ Area Seepline-Average Values } \\
\hline $\begin{array}{c}\text { Sampling Event } \\
\text { Date }\end{array}$ & $\begin{array}{c}\text { tritium } \\
(p \text { Ci/ml })\end{array}$ & $\begin{array}{c}\text { Conductivity } \\
(\mu \mathrm{S} / \mathrm{cm})\end{array}$ & $\boldsymbol{p H}$ & $\begin{array}{c}\text { tritium } \\
(\boldsymbol{p C i} / \mathrm{ml})\end{array}$ & $\begin{array}{c}\text { Conductivity } \\
(\mu \mathrm{S} / \mathrm{cm})\end{array}$ & $\boldsymbol{p H}$ \\
\hline Mar-89 & 3357 & 438 & 4.8 & 8402 & 297 & 5.2 \\
\hline May-92 & 1934 & 335 & 4.7 & 4131 & 183 & 5.9 \\
\hline Sep-92 & 1990 & 352 & 5.2 & 2904 & 182 & 6.0 \\
\hline Dec-92 & 1823 & 300 & 5.3 & 3001 & 165 & 6.0 \\
\hline Mar-93 & 1398 & 293 & 5.0 & 2063 & 124 & 5.9 \\
\hline Jun-93 & 1936 & 330 & 5.1 & 2885 & 157 & 6.0 \\
\hline Sep-93 & 2384 & 404 & 5.0 & 2876 & 205 & 5.7 \\
\hline Dec-93 & 1920 & 415 & 5.1 & 2749 & 181 & 5.7 \\
\hline Mar-94 & 1525 & 371 & 5.0 & 1818 & 140 & 5.6 \\
\hline Jun-94 & 1688 & 344 & 5.0 & 2053 & 153 & 5.8 \\
\hline Sep-94 & 1806 & 381 & 5.1 & 1953 & 159 & 6.0 \\
\hline Dec-94 & 1698 & 366 & 4.9 & 2836 & 179 & 5.8 \\
\hline May-95 & 1634 & 311 & 5.0 & 1547 & 131 & 5.6 \\
\hline Mar-96 & 1424 & 331 & 4.7 & 1082 & 113 & 5.9 \\
\hline Sep-96 & 1545 & 328 & 4.8 & 880 & 142 & 6.1 \\
\hline
\end{tabular}


Table 7. Average Tritium and Conductivity, values for Seepline below 643-E

\begin{tabular}{|c|c|c|c||c|c|c|}
\hline $\begin{array}{c}\text { Sampling } \\
\text { Event Date }\end{array}$ & $\begin{array}{c}\text { Tritium (all) } \\
(p \text { Ci/ml })\end{array}$ & $\begin{array}{c}\text { Tritium }(\text { East }) \\
(p \text { Ci/ml })\end{array}$ & $\begin{array}{c}\text { Tritium (West) } \\
(p \text { Ci/ml })\end{array}$ & $\begin{array}{c}\text { Conductivity } \\
(\text { All })\end{array}(\mu S / c m)$ & $\begin{array}{c}\text { Conductivity }) \\
(\text { East }) \\
(\mu S / c m)\end{array}$ & $\begin{array}{c}\text { Conductivity } \\
(\text { West }) \\
(\mu S / c m)\end{array}$ \\
\hline Mar-93 & 4808 & 242 & 8999 & 62 & 43 & 88 \\
\hline Jun-93 & 7617 & 389 & 14779 & 82 & 53 & 122 \\
\hline Sep-93 & 10924 & 445 & 22017 & 92 & 57 & 140 \\
\hline Dec-93 & 8182 & 435 & 15527 & 68 & 56 & 86 \\
\hline Jun-94 & 8557 & 324 & 14557 & 58 & 53 & 68 \\
\hline Sep-94 & 8065 & 303 & 15469 & 57 & 53 & 65 \\
\hline Dec-94 & no data & no data & no data & no data & no data & no data \\
\hline May-95 & 4323 & 270 & 6630 & 69 & 64 & 79 \\
\hline Mar-96 & 4069 & 143 & 7483 & 43 & 36 & 53 \\
\hline Sep-96 & 4260 & 183 & 7121 & 44 & 37 & 54 \\
\hline
\end{tabular}

- Table 8. Tritium concentrations for Fourmile Branch

\begin{tabular}{|c|c|c||c|c|c|}
\hline Sample date & Sample ID & Tritium $(\mathrm{pCi}$ /ml) & Sample date & Sample ID & Tritium $(\mathrm{pCi} / \mathrm{ml})$ \\
\hline Dec-92 & FMC001H & 55 & Jun-94 & FMC002H & 82 \\
\hline Dec-92 & FMC001F & 455 & Sep-94 & FMC001F & 567 \\
\hline Dec-92 & FMC002H & 2050 & Sep-94 & FMC001H & 52 \\
\hline Apr-93 & FMC001H & 47 & Sep-94 & FMC002H & 93 \\
\hline Apr-93 & FMC001F & 425 & Dec-94 & FMC001F & 312 \\
\hline Apr-93 & FMC002H & 104 & Dec-94 & FMC001H & 59 \\
\hline Sep-93 & FMC001H & 41 & Dec-94 & FMC002H & 113 \\
\hline Sep-93 & FMC002H & 105 & May-95 & FMC001F & 643 \\
\hline Sep-93 & FMC001F & 503 & May-95 & FMC001H & 63 \\
\hline Dec-93 & FMC001H & 37 & May-95 & FMC002H & 97 \\
\hline Dec-93 & FMC001F & 567 & Mar-96 & FMC001F & 138 \\
\hline Dec-93 & FMC002H & 145 & Mar-96 & FMC001H & 34 \\
\hline Mar-94 & FMC001H & 34 & Mar-96 & FMC002H & 65 \\
\hline Mar-94 & FMC001F & 375 & Sep-96 & FMC001F & 520 \\
\hline Mar-94 & FMC002H & 91 & Sep-96 & FMC001H & 35 \\
\hline Jun-94 & FMC001F & 331 & Sep-96 & FMC002H & 76 \\
\hline Jun-94 & FMC001H & 42 & & & \\
\hline
\end{tabular}

